\title{
Dissociation of Gas-Phase, Doubly-Charged Uranyl-Acetone Complexes by Collisional Activation and Infrared Photodissociation
}

\author{
Michael J. Van Stipdonk ${ }^{1 *}$, Catherine $\mathrm{O}^{\prime}$ Malley$^{1}$, Alexandra Plaviak ${ }^{1}$, Dean Martin ${ }^{1}$, \\ Jordan Pestok ${ }^{1}$, Patricia A. Mihm ${ }^{1}$, Cassandra G. Hanley ${ }^{1}$, Theodore A. Corcovilos ${ }^{2}$, \\ John K. Gibson ${ }^{3}$ and Benjamin J. Bythell ${ }^{4}$ \\ ${ }^{1}$ Department of Chemistry and Biochemistry, Duquesne University, Pittsburgh PA 15282 \\ ${ }^{2}$ Department of Physics, Duquesne University, Pittsburgh PA 15282 \\ ${ }^{3}$ Chemical Sciences Division, Lawrence Berkeley National Laboratory, Berkeley CA, 94720 \\ ${ }^{4}$ Department of Chemistry, University of Missouri-St. Louis, St. Louis MO 63121-4400
}

\begin{abstract}
Past studies of fragmentation reactions of doubly-charged uranyl $\left(\mathrm{UO}_{2}{ }^{2+}\right)$ complexes have been impeded by very rapid water addition reactions that cause $\mathrm{H}_{2} \mathrm{O}$ adducts to dominate product ion spectra. The fragmentation of uranyl-acetone (aco) complexes $\left(\left[\mathrm{UO}_{2}(\mathrm{aco}) \mathrm{n}\right]^{2+}, \mathrm{n}=1-5\right)$, generated by electrospray ionization, is revisited here using: (a) collisional activation in a linear ion trap (LIT) mass spectrometer in which the level of background $\mathrm{H}_{2} \mathrm{O}$ is significantly lower, and (b) infrared photodissociation (IRMPD, $10.6 \mu \mathrm{m}$ ) in the LIT and a Fourier-transform ion cyclotron resonance (FT-ICR) mass spectrometer. Lower levels of adventitious $\mathrm{H}_{2} \mathrm{O}$ in the LIT provided access to fragmentation of $\left[\mathrm{UO}_{2}(\mathrm{aco})_{n}\right]^{2+}, \mathrm{n}=1-5$. For $\mathrm{n}=3-5$, direct elimination of aco ligands is the favored fragmentation pathway. For $n=1$ and 2, charge reduction reactions are dominant. For $\left[\mathrm{UO}_{2}(\mathrm{aco})_{2}\right]^{2+}$, the most abundant product ion is $\left[\mathrm{UO}_{2}(\mathrm{aco})\right]^{+}$, while $\mathrm{UO}_{2}{ }^{+}$is observed following collision-induced dissociation (CID) of $\left[\mathrm{UO}_{2}(\mathrm{aco})\right]^{2+}$. Minor peaks corresponding to ligated $\left[\mathrm{UO}_{2} \mathrm{OH}\right]^{+}$are also observed. The IRMPD experiments in the FT-ICR yielded highly accurate mass measurements that confirm composition assignments, and shed light on dissociation reactions in a gasphase environment that is entirely free of adventitious $\mathrm{H}_{2} \mathrm{O}$. For $\left[\mathrm{UO}_{2}(\mathrm{aco})_{n}\right]^{2+}, \mathrm{n}=3-5$, the primary photodissociation channel is direct aco elimination, along with charge-reduction pathways that involve intra-complex proton transfer and formation of species that contain enolate ligands. Similar pathways are observed for IRMPD measurements in the LIT.
\end{abstract}

*To whom correspondence should be addressed:

Department of Chemistry and Biochemistry

Center of Excellence in Mass Spectrometry

Duquesne University

600 Forbes Avenue

Pittsburgh, PA 15282

Phone: 412-396-4923

vanstipdonkm@duq.edu

KEY WORDS: Electrospray ionization, metal complexes, uranyl ion, ion fragmentation, ion trap mass spectrometry 


\subsection{INTRODUCTION}

Exploration of intrinsic (i.e. gas-phase) uranyl ion $\left(\mathrm{UO}_{2}{ }^{2+}\right)$ chemistry in the past was difficult because of the lack of effective methods for generating doubly-charged complexes containing $\mathrm{UO}_{2}{ }^{2+}$. Schwarz and coworkers reported the formation of the "bare" uranyl dication by gas-phase oxidation and charge exchange reactions ${ }^{1}$, which yielded a value for the second ionization potential for $\mathrm{UO}_{2}{ }^{+}$that was consistent with a vertical ionization energy obtained by ab initio calculations. Later, Marçalo, and co-workers used laser desorption/ionization and in situ oxidation to generate gas-phase, divalent actinide dioxo cations for subsequent characterization by Fourier transform ion cyclotron resonance mass spectrometry ${ }^{2}$.

The transfer of uranium as monopositive pentavalent $\mathrm{U}^{v} \mathrm{O}_{2}{ }^{+}$, from solution to the gas phase using electrospray ionization (ESI) was first reported in $1992 .{ }^{3}$ Thereafter, advances in the fundamental understanding of uranyl coordination chemistry have been achieved by using this experimental technique. ${ }^{4-19}$ Most importantly, it has been shown that gas-phase, doubly charged complexes containing the uranyl ion, such as $\left[\mathrm{UO}_{2}(\mathrm{~L})_{\mathrm{n}}\right]^{2+}$, with $\mathrm{L}=$ acetone (aco) or acetonitrile (acn) and $n=4$ or 5 , can be generated by ESI. ${ }^{13}$ Using small species such as acn and aco, the dominant species observed in the ESI mass spectrum contains the uranyl ion coordinated by 5 ligands.

Studies focusing on gas-phase uranyl complexes have since been extended to include transuranics. ${ }^{20-22}$ For example, ESI was used to generate acn and aco complexes of $\mathrm{PuO}_{2}{ }^{2+}$ and $\mathrm{UO}_{2}{ }^{2+}$ solutions using similar experimental conditions. ${ }^{22}$ In accord with relative actinyl stabilities, $\mathrm{UO}_{2}{ }^{2+}>\mathrm{PuO}_{2}{ }^{2+}>\mathrm{NpO}_{2}{ }^{2+}$, the yields of plutonyl complexes with acn or aco were significantly lower than those of uranyl, and dipositive neptunyl complexes were not observed. Collision-induced dissociation (CID) of the dipositive coordination complexes in a 3-D quadrupole ion trap produced doubly and singly charged fragment ions; the fragmentation products revealed differences in underlying chemistries of $\mathrm{PuO}_{2}{ }^{2+}$ and $\mathrm{UO}_{2}{ }^{2+}$, including the lower stability of $\mathrm{Pu}(\mathrm{VI})$ as compared with $\mathrm{U}(\mathrm{VI})$. In a subsequent study, it was discovered that micro-solvated $\mathrm{NpO}_{2}{ }^{2+}$ could be generated if the more strongly binding ligand dimethylformamide was used. ${ }^{23}$ The chemistry of its complexes was then compared to those of $\mathrm{UO}_{2}{ }^{2+}$ and $\mathrm{PuO}_{2}{ }^{2+} \cdot 23$ 
Throughout our past studies of the gas-phase dissociation behavior of actinyl complexes, multiple-stage CID experiments have suggested that doubly charged complexes containing, for example, aco do not shed their full complement of coordinating ligands, but instead generate hydrated product ions $\left(\mathrm{H}_{2} \mathrm{O}\right.$ replacing aco ligands eliminated in the CID reactions), or undergo charge reduction reactions to cations such as $\left[\mathrm{UO}_{2} \mathrm{OH}\right]^{+}$and $\left[\mathrm{UO}_{2}\right]^{+}$ coordinated by aco and/or $\mathrm{H}_{2} \mathrm{O} \cdot \cdot^{13,14,22}$ Ligand addition reaction rates were so fast that complexes with 2 or 3 coordinating aco ligands hydrated to generate heterogeneous, tetra- or pentacoordinate complexes. As a consequence, gas-phase complex ions containing $\mathrm{UO}_{2}{ }^{2+}$ and two or fewer ligands could not be generated by CID in a "top-down" approach.

In the present study, we used a linear quadrupole ion trap (LIT) to re-examine the fragmentation of uranyl-aco complex ions. The same instrument was used recently to investigate the fragmentation behavior of uranyl complexes with acetonitrile, ${ }^{24}$ and we showed that the amount of adventitious $\mathrm{H}_{2} \mathrm{O}$ and $\mathrm{CH}_{3} \mathrm{OH}$ in the LIT is significantly lower than in the 3D ion trap employed in our previous studies. The low partial pressures of the neutrals therefore allowed the fragmentation chemistry of the species to be studied more completely. For example, we found that CID could be used to drive ligand elimination to completion and furnish the bare uranyl dication, $\mathrm{UO}_{2}{ }^{2+}$. In addition, fragmentation of $\left[\mathrm{UO}_{2}(\mathrm{acn})\right]^{2+}$ generated $\left[\mathrm{UO}_{2} \mathrm{NC}^{+}\right.$, which subsequently fragmented to furnish $\mathrm{NUO}^{+}$. Creation of the nitrido species by transfer of $\mathrm{N}$ from cyanide was confirmed using precursors labeled with ${ }^{15} \mathrm{~N}$, and a formation mechanism involving a cyanate intermediate was proposed based on density functional theory calculations. The bare $\mathrm{NUO}^{+}$ion, which is isoelectronic with $\mathrm{UO}_{2}{ }^{2+}$, had previously been prepared in a "bottom-up" approach by insertion of $\mathrm{U}^{+}$into NO in an ion-molecule reaction. ${ }^{25}$

As described below, the lower partial pressures of adventitious $\mathrm{H}_{2} \mathrm{O}$ in the LIT minimized adduct formation and also allowed access to lower uranyl coordination numbers than previously possible for aco-ligated $\mathrm{UO}_{2}{ }^{2+}$. We have now been able to investigate the fragmentation behavior of the complete series of complex ions, $\left[\mathrm{UO}_{2}(\mathrm{aco})_{n}\right]^{2+}, \mathrm{n}=1-5$, with a focus on the tendency for species to undergo ligand elimination versus charge reduction reactions. The low levels of adventitious $\mathrm{H}_{2} \mathrm{O}$ and $\mathrm{CH}_{3} \mathrm{OH}$ in the ion trap allowed for a more controlled synthesis of adducts for investigation of their fragmentation behavior, and a study of the 
general trends in reactivity of specific precursor ions with both neutrals in ion-molecule reactions. These results were compared to data collected on a Fourier-transform ion cyclotron resonance (FT-ICR) MS where the pressure is such that the probability of a collision with a $\mathrm{H}_{2} \mathrm{O}$ molecule is essentially zero. IRMPD activation of the uranyl complexes was used in this instrument due to the lack of surrounding gas.

\subsection{EXPERIMENTAL METHODS}

\subsection{CID and IRMPD experiments using a linear ion trap mass spectrometer}

ESI followed by CID experiments were performed on a ThermoScientific (San Jose, CA) LTQ-XL LIT mass spectrometer equipped with an Ion Max ESI source. For the ESI experiments, a stock solution (approximately 0.001 molar) of uranyl nitrate hexahydrate $\left(\mathrm{UO}_{2}\left(\mathrm{NO}_{3}\right)_{2} \bullet\left(\mathrm{H}_{2} \mathrm{O}\right)_{6}\right)$ was prepared in water/aco or water/d6-aco in a 90:10 (v:v) ratio. More dilute solutions were prepared by adding 90:10 water/aco or water/d 6 aco to the stock solution. The aco concentration was kept low to prevent its introduction into the ion trap at partial pressures high enough to complicate the studies of reactions between uranyl-aco complexes and $\mathrm{H}_{2} \mathrm{O}$.

The uranyl- $\mathrm{H}_{2} \mathrm{O}$-aco solution was infused into the ESI-MS instrument using the incorporated syringe pump at a flow rate of $5 \mu \mathrm{l} / \mathrm{min}$. The atmospheric pressure ionization stack settings for the LTQ (lens voltages, quadrupole and octopole voltage offsets, etc.) were optimized for maximum transmission of the doubly-charged ions $\left[\mathrm{UO}_{2}(\operatorname{aco})_{4}\right]^{2+}$ and $\left[\mathrm{UO}_{2}(\mathrm{aco})_{5}\right]^{2+}$ to the ion trap mass analyzer by using the auto-tune routine within the LTQ Tune program. Helium was used as the bath/buffer gas to improve trapping efficiency and as the collision gas for CID experiments.

For CID, precursor ions were isolated using an isolation width of 1.0 to 1.5 mass to charge $(\mathrm{m} / \mathrm{z})$ units. The exact value was determined empirically to provide maximum ion intensity while ensuring isolation of a single isotopic peak. The (mass) normalized collision energy (NCE, as defined by ThermoScientific) was set between 5 and 18\%, which corresponds to application of $0.55-0.68 \mathrm{~V}$ tickle voltage to the end cap electrodes with the current instrument calibration. The activation $Q$, which defines the frequency of the applied R.F. potential, was set at 0.30 . In all cases, the activation time employed was $30 \mathrm{~ms}$. The mass 
spectra displayed represent the accumulation and averaging of at least 30 isolation, dissociation and ejection/detection steps.

The LIT has been modified to accommodate laser beams by cutting a 16-mm diameter hole into the aluminum accessory flange, coaxial with the ion trap. Over this hole sits a replaceable 25.4-mm diameter, 5-mm thick ZnSe window (Thorlabs part WG71050, Newton, NJ, USA), clamped to the aluminum plate with a CF 2-1/8" flange held in place by four socket-cap screws. A high-vacuum seal is made by placing a fluoroelastomer o-ring between the window and the plate. An additional o-ring sits between the window and flange to protect the window from stress-induced deformation or damage. Radiation from a $\mathrm{CO}_{2}$ laser $(\lambda=10.6 \mu \mathrm{m}$, Synrad model 48-2, Mukilteo, WA) with output beam radius of $1.75 \mathrm{~mm}\left(1 / \mathrm{e}^{2}\right.$ radius) and nominal CW output power of $25 \mathrm{~W}$ is shaped before entering the ion trap. The bean is condensed by a factor of 1.5 using a ZnSe Galilean telescope, and then focused with plano-convex ZnSe lens with a nominal focal length of $+150 \mathrm{~mm}$, to produce a $1 / \mathrm{e}^{2}$ beam radius at the focus (inside the ion trap) of $\sim 250 \mu \mathrm{m}$ and a Rayleigh range of $\sim 20 \mathrm{~mm}$.

The average laser power is controlled by pulse-width modulation of the laser output and by insertion or removal of beam splitters in the beam path. At the highest modulation frequency of $20 \mathrm{kHz}$ the maximum peak-to-peak variation in the laser power is estimated to be $\sim 15 \%$. The laser is mounted on an adjacent vibration-isolated optical table approximately $27 \mathrm{~cm}$ below the window. A periscope consisting of two gold-plated copper mirrors (Thorlabs NB1L01) mounted in 2-axis kinematic mounts (Thorlabs KCB1) and an XY translation stage (Thorlabs CXY2) holding the final lens are used to align the laser beam with the ion trap. The total beam path between the laser head and the window is approximately $1.2 \mathrm{~m}$ long. This length allows the insertion of removable beamsplitters (for attenuating the laser power), addition of lenses for optimizing the beam diameter and divergence, and optics for incorporating other lasers into the system.

\subsection{IRMPD experiments using a FT-ICR mass spectrometer}

The experiments were also performed with a custom-built 9.4 T ESI FT-ICR mass spectrometer recently described in detail. ${ }^{26}$ Samples of $\mathrm{UO}_{2}\left(\mathrm{NO}_{3}\right)_{2} \bullet\left(\mathrm{H}_{2} \mathrm{O}\right)_{6}$ in $\mathrm{H}_{2} \mathrm{O}$ and acetone, 
prepared as for the LIT experiments, were infused into a tapered $50 \mu \mathrm{m}$ i.d. fused silica micro-

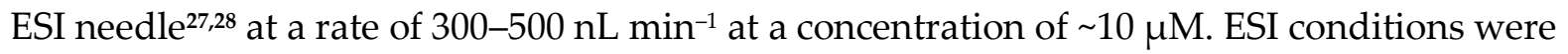
needle voltage $2 \mathrm{kV}$ and heated capillary current $2.5 \mathrm{~A}$. The capillary current was deliberately set to a low value to ensure minimal thermal dissociation of the complex ions. Transport between the quadrupoles was effected with as low a voltage as possible to limit energy of the collisions experienced. A potential of $2 \mathrm{~V}$ was applied to the end cap and compensation electrodes of the ICR cell to minimize the axial extent of the ion cloud ${ }^{29}$. Where possible, the analyte ions of interest were isolated, then accumulated in quadrupole 2 prior to transfer to the ICR cell. Additional or alternate means of isolation were provided by stored waveform inverse Fourier transform (SWIFT) $)^{30,31}$ mass-selective ion ejection in the ICR cell. IRMPD experiments were performed by with a Synrad $\mathrm{CO}_{2}$ laser. The laser is mounted off-axis $\left(\sim 3.5^{\circ}\right)$ due to the need to accommodate an axially-mounted electron capture dissociation cathode. To ensure complete irradiation of the ion cloud ${ }^{32}$, the laser beam diameter $(3.5 \mathrm{~mm})$ was expanded to $\sim 9$ $\mathrm{mm}$ by means of a 2.5-fold beam expander (Synrad). Typical (uncorrected) base pressure for the instrument was $\leq 2 \times 10^{-10}$ Torr, measured by a Bayard-Alpert ionization gauge.

Instrument control, data acquisition, and data analysis were carried out with a modular ICR data station ${ }^{33}$. Data acquisition was automated by use of a tool command language script. Each time domain ICR signal (sum of 50 transients) was Hanning apodized, then zero-filled once $^{34}$, and Fourier transformed to generate a magnitude-mode spectrum that is converted to mass-to-charge ratio by a two-term calibration equation ${ }^{35}$.

\subsection{RESULTS AND DISCUSSION}

\section{$\underline{3.1 \mathrm{CID} \text { of }\left[\mathrm{UO}_{2}(\mathrm{aco})_{5}\right]^{2+} \text { and }\left[\mathrm{UO}_{2}(\mathrm{aco})_{4}\right]^{2+}}$}

Figure 1 shows the full ESI mass spectrum generated using the LIT mass spectrometer and spray solution of $\mathrm{UO}_{2}\left(\mathrm{NO}_{3}\right)_{2} \bullet\left(\mathrm{H}_{2} \mathrm{O}\right)_{6}$ in 90:10 (v:v) water/aco. As in our previous study, ${ }^{13}$ the most abundant doubly-charged complex ions generated were $\left[\mathrm{UO}_{2}(\operatorname{aco})_{4}\right]^{2+}$ and $\left[\mathrm{UO}_{2}(\mathrm{aco})_{5}\right]^{2+}$. Insets in Figure 1 show expanded views of two of the uranyl-aco complexes, which reveal the $\mathrm{C}-13$ isotopic peak spacing that indicates the +2 charge state of the ions. 
The CID spectra generated from $\left[\mathrm{UO}_{2}(\mathrm{aco})_{n}\right]^{2+}, \mathrm{n}=1-4$, are shown in Figure 2. CID (MS/MS stage) of $\left[\mathrm{UO}_{2}(\mathrm{aco})_{5}\right]^{2+}$ at $\mathrm{m} / \mathrm{z} 280$ generated only $\left[\mathrm{UO}_{2}(\mathrm{aco})_{4}\right]^{2+}$ at $\mathrm{m} / \mathrm{z} 251$ and the product ion spectrum is not shown in Figure 2. The dominant product ion generated by the subsequent $\mathrm{CID}$ of $\left[\mathrm{UO}_{2}(\mathrm{aco})_{4}\right]^{2+}\left(\mathrm{MS}^{3}\right.$ stage, Figure $\left.2 \mathrm{a}\right)$ was $\left[\mathrm{UO}_{2}(\mathrm{aco})_{3}\right]^{2+}$ at $\mathrm{m} / \mathrm{z} 222$, a result of elimination of a single aco ligand, and the intensity of the monohydrate, $\left[\mathrm{UO}_{2}(\mathrm{aco}){ }_{3}\left(\mathrm{H}_{2} \mathrm{O}\right)\right]^{2+}$ at $\mathrm{m} / \mathrm{z} 231$, is $<10 \%$ relative to $\left[\mathrm{UO}_{2}(\mathrm{aco})_{3}\right]^{2+}$. This observation is in sharp contrast to our earlier study using the 3-D quadrupole ion trap, ${ }^{13}$ in which the relative intensity of $\left[\mathrm{UO}_{2}(\mathrm{aco})_{3}\right]^{2+}$ was $<$ $5 \%$ relative to the mono- and di-hydrates, $\left[\mathrm{UO}_{2}(\mathrm{aco})_{3}\left(\mathrm{H}_{2} \mathrm{O}\right)\right]^{2+}$ and $\left[\mathrm{UO}_{2}(\mathrm{aco})_{3}\left(\mathrm{H}_{2} \mathrm{O}\right)_{2}\right]^{2+}, \mathrm{m} / \mathrm{z} 231$ and 240, respectively. We attribute the difference in the product ion distributions to a lower partial pressure of $\mathrm{H}_{2} \mathrm{O}$ in the LIT, whether by change in instrument geometry and design or better vacuum conditions. In any case, it is clear that the tendency to form $\mathrm{H}_{2} \mathrm{O}$ adducts to the uranyl complexes in the ion trap is reduced significantly in the present experiments. The same observation was made in our recent investigation of acetonitrile-coordinated uranyl ion. ${ }^{24}$

\section{2 $\mathrm{CID}$ of $\left[\mathrm{UO}_{2}(\mathrm{aco})_{3}\right]^{2+}$}

The dominant product ion generated by CID of $\left[\mathrm{UO}_{2}(\mathrm{aco})_{3}\right]^{2+}$ at $m / z 222\left(\mathrm{MS}^{4}\right.$ stage, figure $2 b$ ) was $\left[\mathrm{UO}_{2}(\text { aco })_{2}\right]^{2+}$ at $m / z$ 193, again by elimination of a single aco ligand, with an $\mathrm{H}_{2} \mathrm{O}$ adduct $(\mathrm{m} / \mathrm{z} 202)$ observed at $\sim 10 \%$ relative intensity. Product ions generated through chargereduction pathways, at $m / z$ 345, 385 and 403, were observed at relative intensities below 20\% relative to the $\left[\mathrm{UO}_{2}(\mathrm{aco})_{2}\right]^{2+}$ fragment. The ion at $\mathrm{m} / \mathrm{z} 345$ is attributed to $\left[\mathrm{UO}_{2} \mathrm{OH}(\mathrm{aco})\right]^{+}$, the formation of which presumably involves a reactive collision with background $\mathrm{H}_{2} \mathrm{O}$, and elimination of both a neutral and protonated aco ligand as shown in reaction 1 . The latter product appears in the CID spectrum at $m / z$ 59. Subsequent CID (spectrum not shown) of the ion at $\mathrm{m} / \mathrm{z} 345$ generates a product ion at $\mathrm{m} / \mathrm{z} 287\left(\mathrm{UO}_{2} \mathrm{OH}^{+}\right)$, consistent with the composition assignment.

(1) $\left[\mathrm{UO}_{2}(\mathrm{aco})_{3}\right]^{2+}+\mathrm{H}_{2} \mathrm{O} \rightleftharpoons\left[\mathrm{UO}_{2} \mathrm{OH}(\mathrm{aco})\right]^{+}+(\mathrm{aco}+\mathrm{H})^{+}+\mathrm{aco}^{\circ}$

We assume that the ion at $m / z 403,\left[\mathrm{UO}_{2} \mathrm{OH}(\mathrm{aco})_{2}\right]^{+}$, is generated in a similar process, but without elimination of the neutral aco ligand. The product ions at $m / z 345$ and 403 were both 
observed in our earlier study of $\left[\mathrm{UO}_{2}(\mathrm{aco})_{n}\right]^{2+}$ ion CID. ${ }^{13}$ However, the relatively low ion intensities of these ions further illustrate the significantly lower partial pressure of (background) $\mathrm{H}_{2} \mathrm{O}$ in the LIT instrument.

The relatively abundant product ion at $m / z 385$ was not observed as a fragment of $\left[\mathrm{UO}_{2}(\mathrm{aco})_{3}\right]^{2+}$ in our earlier study ${ }^{13}$, and is assigned to a species with composition $\left[\mathrm{UO}_{2}(\right.$ aco$\mathrm{H})(\mathrm{aco})]^{+}$. We presume that the charge-reduction reaction to generate this ion involves intracomplex proton transfer, elimination of protonated aco, and retention of deprotonated acetone anion (enolate) as shown in reaction 2. Transfer of a D atom to create an (aco+D)+ product was observed in experiments with analogous complexes composed of $\mathrm{UO}_{2}{ }^{2+}$ coordinated by $\mathrm{d}_{6}$-aco (spectrum not shown).

(2) $\left[\mathrm{UO}_{2}(\mathrm{aco})_{3}\right]^{2+} \rightarrow\left[\mathrm{UO}_{2}(\mathrm{aco}-\mathrm{H})(\mathrm{aco})\right]^{+}+(\mathrm{aco}+\mathrm{H})^{+}$

Subsequent CID of the ion at $m / z 385$ yielded a product ion at $m / z 327$ (Figure 3a). The neutral loss in this dissociation reaction is 58 mass units, consistent with formation of $\left[\mathrm{UO}_{2}\right.$ (aco$\mathrm{H}$ ) $]^{+}$. CID of the ion at $m / z 327$ (Figure $3 b$ ) generated product ions at $m / z 270$ and 287, assigned as $\mathrm{UO}_{2}{ }^{+}$and $\mathrm{UO}_{2} \mathrm{OH}^{+}$, respectively, and at $m / z 271$ and 288. The latter two are assigned to $\mathrm{UO}_{2} \mathrm{H}^{+}$and $\mathrm{UO}_{2}\left(\mathrm{H}_{2} \mathrm{O}\right)^{+}$, respectively.

At first glance, the appearance of products such as $\mathrm{UO}_{2} \mathrm{OH}^{+}$and $\mathrm{UO}_{2}\left(\mathrm{H}_{2} \mathrm{O}\right)^{+}$is best explained by invoking dissociation reactions that involve collisions with background $\mathrm{H}_{2} \mathrm{O}$, similar to those reported in our earlier study ${ }^{13}$. To probe the dissociation pathways for $\left[\mathrm{UO}_{2}(\mathrm{aco}-\mathrm{H})\right]^{+}$further, we examined the CID of the analogous ion generated from precursors that contained $\mathrm{d}_{6}$-aco. $\mathrm{CID}$ of $\left[\mathrm{UO}_{2}\left(\mathrm{~d}_{6} \mathrm{aco}-\mathrm{D}\right)\right]^{+}(\mathrm{m} / \mathrm{z} 332$, figure $3 \mathrm{c})$ generated $\mathrm{UO}_{2}{ }^{+}$at $\mathrm{m} / z$ 270, and $\mathrm{UO}_{2} \mathrm{D}^{+}$at $m / z$ 272. The mass shift of 1 unit $\left(\mathrm{m} / \mathrm{z} 271\right.$ to $\mathrm{m} / z$ 272) shows that $\mathrm{UO}_{2} \mathrm{H}^{+}$(from the unlabeled precursor ion) is generated by hydride transfer from the deprotonated acetone ligand.

(3) $\left[\mathrm{UO}_{2}\left(\mathrm{~d}_{6} \mathrm{aco}-\mathrm{D}\right)\right]^{+} \rightarrow\left[\mathrm{UO}_{2} \mathrm{D}\right]^{+}+\left(\mathrm{d}_{6} \mathrm{aco}-2 \mathrm{D}\right)$

CID of $\left[\mathrm{UO}_{2}\left(\mathrm{~d}_{6} \mathrm{aco}-\mathrm{D}\right)\right]^{+}$at $\mathrm{m} / \mathrm{z} 332$ also generated the product ions at $\mathrm{m} / \mathrm{z} 287$ and 288. The intensity of the species at $m / z 288$ is greater than was observed following CID of [ $\mathrm{UO}_{2}$ (aco$\mathrm{H})]^{+}$(Figure $3 \mathrm{~b}$ ), suggesting that the peak may correspond to formation of $\mathrm{UO}_{2} \mathrm{OD}^{+}$. If this is the 
case, then the dissociation channel suggests that formation of uranyl hydroxide from $\left[\mathrm{UO}_{2}(\right.$ aco$\mathrm{H})]^{+}(\mathrm{m} / \mathrm{z} 287$ in Figure 3b) may involve, to some extent, decomposition of the deprotonated acetone ligand rather than exclusively reactive collisions with background $\mathrm{H}_{2} \mathrm{O}$.

CID of the ion at $m / z 327$ also generated a product ion at $m / z 299$ (Figure 3b). The neutral loss associated with formation of this product ion is 28 mass units, suggesting either elimination of $\mathrm{CO}$ or $\mathrm{CH}_{2}=\mathrm{CH}_{2}$. For the analogous precursor ions that contained d6aco, CID of [ $\mathrm{UO}_{2}\left(\mathrm{~d}_{6}\right.$ acoD) $]^{+}$(Figure 3c), generated peaks at $\mathrm{m} / \mathrm{z} 300$ and $\mathrm{m} / \mathrm{z}$ 304. The peak at $\mathrm{m} / \mathrm{z} 300$ would be the

(4) $\left[\mathrm{UO}_{2}(\text { aco- } \mathrm{H})\right]^{+} \rightarrow\left[\mathrm{UO}_{2}(\mathrm{O}=\mathrm{CH})\right]^{+}+\mathrm{CH}_{2}=\mathrm{CH}_{2}$

(5) $\left[\mathrm{UO}_{2}(\mathrm{aco}-\mathrm{H})\right]^{+} \rightarrow\left[\mathrm{UO}_{2}\left(\mathrm{CH}_{2}-\mathrm{CH}_{3}\right)\right]^{+}+\mathrm{CO}$

product expected for loss of $\mathrm{CD}_{2}=\mathrm{CD}_{2}$, and the composition assignment for the ion at $\mathrm{m} / \mathrm{z} 300$ is therefore $\left[\mathrm{UO}_{2}(\mathrm{DCO})\right]^{+}\left(\left[\mathrm{UO}_{2}(\mathrm{HCO})\right]^{+}\right.$for the unlabeled precursor). The peak at $\mathrm{m} / \mathrm{z} 304$ is the product expected for pathway that involves loss of $\mathrm{CO}$ from $\left[\mathrm{UO}_{2}\left(\mathrm{~d}_{6}-\mathrm{aco}-\mathrm{D}\right)\right]^{+}$. Comparing the fragmentation of native and deuterium labeled $\left[\mathrm{UO}_{2}(\mathrm{aco}-\mathrm{H})\right]^{+}$thus suggests that the elimination of 28 mass involves independent channels that lead to loss of $\mathrm{CH}_{2}=\mathrm{CH}_{2}$ or of $\mathrm{CO}$ as shown in reactions 4 and 5 .

The mechanism by which CO may be eliminated is not known and would benefit from a detailed computation investigation. We note that the conversion of (intact) aco to formaldehyde, with associated elimination of ethylene, has been reported for CID experiments involving aco-coordinated transition metal cations ${ }^{36}$. Hagelberg, Shvartsburg and coworkers investigated the mechanism for elimination of $\mathrm{CH}_{2}=\mathrm{CH}_{2}$ in detail using DFT calculations, and found that the process likely involves a multi-step pathway and formation of an intermediate propionaldehyde ligand ${ }^{36}$. A particularly interesting feature of reaction 5 is that the product corresponds to an organouranyl complex with discrete uranium-carbon bonding; the most likely structure is $\left[\mathrm{O}_{2} \mathrm{U}-\mathrm{CH}_{2}-\mathrm{CH}_{3}\right]^{+}$.

\section{$\underline{3.3 \mathrm{CID} \text { of }\left[\mathrm{UO}_{2}(\mathrm{aco})_{2}\right]^{2+}}$}

In our prior study ${ }^{13}$, collection of product ion spectra for $\left[\mathrm{UO}_{2}(\mathrm{aco})_{2}\right]^{2+}$ and $\left[\mathrm{UO}_{2}(\mathrm{aco})\right]^{2+}$ required isolation of the species directly from the ESI source rather than by creating them in a 
"top-down" approach using multiple-stage CID. With the 3-D ion trap, the product ion spectrum generated from $\mathrm{CID}$ of $\left[\mathrm{UO}_{2}(\mathrm{aco})_{2}\right]^{2+}$ was dominated by $\left[\mathrm{UO}_{2} \mathrm{OH}\right]^{+},\left[\mathrm{UO}_{2} \mathrm{OH}(\mathrm{aco})\right]^{+}$and the mono-and di-hydrates of $\left[\mathrm{UO}_{2} \mathrm{OH}(\mathrm{aco})\right]^{+}$. Using the LIT in the present study, the high abundance of $\left[\mathrm{UO}_{2}(\mathrm{aco})_{2}\right]^{2+}$ created by dissociation of $\left[\mathrm{UO}_{2}(\mathrm{aco})_{3}\right]^{2+}$ allowed us to continue the serial CID $\left(\mathrm{MS}^{\mathrm{n}}\right)$ experiments. The dominant product ion generated by $\mathrm{CID}$ of $\left[\mathrm{UO}_{2}(\mathrm{aco})_{2}\right]^{2+}$ (MS 5 stage, Figure 2c) appears at $m / z$ 328. This peak is assigned to $\left[\mathrm{UO}_{2}(\mathrm{aco})\right]^{+}$, which must be generated in a process that involves reduction of uranyl to $\mathrm{UO}_{2}{ }^{+}$, and oxidation of one of the aco ligands. We note that the complementary peak corresponding to (oxidized) aco radical cation is observed at $\mathrm{m} / \mathrm{z} 58$ (inset in Figure 2 c). Other less abundant ( $<20 \%$ relative intensity) singlycharged product ions included $\left[\mathrm{UO}_{2}(\text { aco- } \mathrm{H})\right]^{+}$at $\mathrm{m} / z 327$ and $\left[\mathrm{UO}_{2} \mathrm{OH}(\text { aco })\right]^{+}$at $\mathrm{m} / z$ 345. The former is likely generated in the same type of proton-transfer process that furnishes the product ion at $m / z 385$ that appears in the CID spectrum of $\left[\mathrm{UO}_{2}(\mathrm{aco})_{3}\right]^{2+}$.

Also present in the CID spectrum of $\left[\mathrm{UO}_{2}(\mathrm{aco})_{2}\right]^{2+}$ is a doubly-charged product ion at $\mathrm{m} / \mathrm{z}$ 179 in the CID spectrum of $\left[\mathrm{UO}_{2}(\mathrm{aco})_{2}\right]^{2+}$ that arises from the net elimination of 28 mass units (twice the measured neutral loss of $14 \mathrm{~m} / \mathrm{z}$ from the doubly charged precursor). Subsequent CID of the species at $\mathrm{m} / \mathrm{z} 179$ (Figure 1a of the supporting information) generated a peak at $\mathrm{m} / \mathrm{z}$ 164 , consistent with formation of $\left[\mathrm{UO}_{2}(\mathrm{aco})\right]^{2+}$ through the net elimination of 30 mass units (twice the measured neutral loss of $15 \mathrm{~m} / \mathrm{z}$ ). To identify the neutral species eliminated during fragmentation of $\left[\mathrm{UO}_{2}(\mathrm{aco})_{2}\right]^{2+}, \mathrm{CID}$ was performed using complex ions that contained $\mathrm{d}_{6}$-aco. CID of $\left[\mathrm{UO}_{2}\left(\mathrm{~d}_{6}-\mathrm{aco}\right)_{2}\right]^{2+}$ (spectrum not shown) at $\mathrm{m} / \mathrm{z} 199$ produced a peak at $\mathrm{m} / \mathrm{z} 183$, representing a shift of $4 \mathrm{~m} / \mathrm{z}$ units relative to the un-labeled complex and indicating that the product ion contains $8 \mathrm{H} / \mathrm{D}$ atoms. Subsequent CID of the species at $m / z 183$ (Figure $1 \mathrm{~b}$ of the supporting information) produced an ion at $m / z 167$ (net loss of $32 \mathrm{u}$ ), demonstrating that the neutral eliminated to furnish $\left[\mathrm{UO}_{2}(\mathrm{aco})\right]^{2+} /\left[\mathrm{UO}_{2}\left(\mathrm{~d}_{6}-\mathrm{aco}\right)\right]^{2+}$ contains $2 \mathrm{H} / \mathrm{D}$ atoms. The observed shifts in product ion $m / z$ values, and neutral losses during CID, strongly suggest that the ion at $m / z 179$ in Figure $2 \mathrm{c}$ is $\left[\mathrm{UO}_{2}(\mathrm{aco})\left(\mathrm{CH}_{2}=\mathrm{O}\right)\right]^{2+}$, created through the elimination of $\mathrm{CH}_{2}=\mathrm{CH}_{2}$.

The pathway involving the apparent loss of ethylene was not observed in our previous investigation $^{13}$, primarily because of the lack of access to the ligand elimination reactions of complexes with 2 or 1 aco ligand due to the pronounced formation of $\mathrm{H}_{2} \mathrm{O}$ adducts in earlier 
CID stages. As noted above, the conversion of aco to formaldehyde is not unprecedented, based on the CID experiments reported by Hagelberg, Shvartsburg and coworkers ${ }^{36}$. Our results demonstrate that similar chemistry is observed for uranyl complexes with aco.

\section{$\underline{3.4 \mathrm{CID} \text { of }\left[\mathrm{UO}_{2}(\mathrm{aco})\right]^{2+}}$}

Another significant finding in the present study was that $\left[\mathrm{UO}_{2}(\mathrm{aco})\right]^{2+}$ was generated in sufficient quantity from dissociation of $\left[\mathrm{UO}_{2}(\mathrm{aco})\left(\mathrm{CH}_{2}=\mathrm{O}\right)\right]^{2+}$ to permit an examination of its fragmentation behavior in the multiple-stage CID experiments. The CID spectrum (MS6 stage) of $\left[\mathrm{UO}_{2}(\mathrm{aco})\right]^{2+}$ is shown in Figure $2 \mathrm{~d}$. Fragment ions included the charge reduction products $\left[\mathrm{UO}_{2}\right]^{+}$at $\mathrm{m} / \mathrm{z} 270$, and $\left[\mathrm{UO}_{2} \mathrm{OH}\right]^{+}$at $\mathrm{m} / \mathrm{z} 287$ and the complementary ions aco and $(\mathrm{aco}+\mathrm{H})^{+}$at $m / z 58$ and 59, respectively. The $\left[\mathrm{UO}_{2} \mathrm{OH}\right]^{+}$and complementary $(\mathrm{aco}+\mathrm{H})^{+}$evidently result from a reactive collision with $\mathrm{H}_{2} \mathrm{O}$. It is interesting to note that the bare uranyl ion at $\mathrm{m} / z 135$ was not observed following $\mathrm{CID}$ of $\left[\mathrm{UO}_{2}(\mathrm{aco})\right]^{2+}$, while it was observed in our recent investigation of analogous complex ions that contained acn. ${ }^{24}$ Because the ionization energy of $\mathrm{UO}_{2}{ }^{+}(14.6 \pm 0.4$ $\mathrm{eV}^{37}$ ) exceeds that of acn $\left(12.2 \mathrm{eV}^{38}\right)$, we hypothesized that fragmentation by charge separation of $\left[\mathrm{UO}_{2}(\mathrm{acn})\right]^{2+}$ to $\mathrm{UO}_{2}{ }^{+}$and $\mathrm{acn}^{+}$should be energetically favored over the elimination of neutral acn. The formation of bare $\mathrm{UO}_{2}{ }^{2+}$ from $\left[\mathrm{UO}_{2}(\mathrm{acn})\right]^{2+}$ was therefore attributed to a Coulomb barrier to charge separation to produce $\mathrm{UO}_{2}{ }^{+}$and $\mathrm{acn}^{+} .{ }^{39}$ The different apparent behavior for complexes containing acn and aco is consistent with the differences in ionization potential for the two neutrals (ionization energy for aco is $9.703 \pm 0.006 \mathrm{eV}^{38}$ ) and may also reflect a lower coulomb barrier for charge separation.

It should also be pointed out that loss of $\mathrm{H}_{2} \mathrm{O}$ from $\left[\mathrm{UO}_{2}(\mathrm{aco})_{n}\right]^{2+}, \mathrm{n}=1-4$, was not observed in the experiments that produced the data shown in Figure 2. In a previous study that used ESI of uranyl-aco solutions to create gas-phase complex ions, a combination of mass spectrometry experiments ${ }^{11}$ and quantum chemical calculations ${ }^{12}$ revealed $\mathrm{H}_{2} \mathrm{O}$ elimination processes that involved aldol dehydration of diacetone alcohol (DAA) ligands, present within the "hypercoordinated" complexes, to produce mesityl oxide (MOX). Because of the lack of product ions corresponding to a net neutral loss of $18 \mathrm{u}$ from any of the $\left[\mathrm{UO}_{2}(\mathrm{aco})_{n}\right]^{2+}$ 
precursors, we can conclude that formation of coordinating DAA ligands, or decomposition of DAA to MOX, did not occur in our LIT experiments.

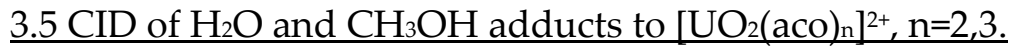

Though the formation of $\mathrm{H}_{2} \mathrm{O}$ adducts to $\mathrm{CID}$ products ions was less pronounced in the present study compared to prior ion trap investigations, many of these species could be generated in sufficient abundance by isolating $\left[\mathrm{UO}_{2}(\mathrm{aco})_{\mathrm{n}}\right]^{2+}, \mathrm{n}=1-3$, for $500-1000 \mathrm{msec}$ without imposed collisional activation. This allowed us to determine the fragmentation pathways of the adduct ions by subsequent CID. As noted earlier, isolation of $\left[\mathrm{UO}_{2}(\mathrm{aco})_{5}\right]^{2+}$ and $\left[\mathrm{UO}_{2}(\mathrm{aco})_{4}\right]^{2+}$ failed to generate adduct ions with intensities suitable for subsequent CID stages.

Figure 4 shows the CID spectra for $\left[\mathrm{UO}_{2}(\mathrm{aco})_{3}\left(\mathrm{H}_{2} \mathrm{O}\right)\right]^{2+}(m / z 231$, Figure $4 \mathrm{a})$ and $\left[\mathrm{UO}_{2}(\mathrm{aco})_{3}(\mathrm{CH} 3 \mathrm{OH})\right]^{2+}(\mathrm{m} / z 238$, figure $4 \mathrm{~b})$. The latter is generated by addition of $\mathrm{CH}_{3} \mathrm{OH}$ presumably present in the ion trap because of its use as a co-solvent in unrelated studies by our group of peptide ion fragmentation with the LIT. It was previously demonstrated that $\left[\mathrm{UO}_{2}(\mathrm{aco})_{3}\left(\mathrm{O}_{2}\right)\right]^{+}$is produced by addition of adventitious oxygen to $\left[\mathrm{UO}_{2}(\mathrm{aco})_{3}\right]^{+}$in an ion trap ${ }^{40,41}$. The assignment here of the ligand as $\mathrm{CH}_{3} \mathrm{OH}$ rather than isobaric $\mathrm{O}_{2}$ is based on the very different chemistry of $\mathrm{U}(\mathrm{VI})$ and $\mathrm{U}(\mathrm{V})$, the latter of which is oxidized by addition of $\mathrm{O}_{2}$, as well as by the distinctive methanol chemistry discussed below. CID of $\left[\mathrm{UO}_{2}(\operatorname{aco})_{3}\left(\mathrm{H}_{2} \mathrm{O}\right)\right]^{2+}$ leads primarily to formation of $\left[\mathrm{UO}_{2}(\text { aco })_{3}\right]^{2+}$ by simple elimination of $\mathrm{H}_{2} \mathrm{O}$. The $\mathrm{CH}_{3} \mathrm{OH}$ adduct $(\mathrm{m} / \mathrm{z}$

(6) $\left[\mathrm{UO}_{2}(\mathrm{aco})_{3}\left(\mathrm{H}_{2} \mathrm{O}\right)\right]^{2+} \rightarrow\left[\mathrm{UO}_{2} \mathrm{OH}(\mathrm{aco})_{2}\right]^{+}+(\mathrm{aco}+\mathrm{H})^{+}$

238) is also generated either by a ligand exchange process or by direct addition to the $\mathrm{m} / z 222$

product ion. The insets in Figure 3a highlight $(\mathrm{aco}+\mathrm{H})^{+}$and $\left[\mathrm{UO}_{2} \mathrm{OH}(\mathrm{aco})_{2}\right]^{+}$peaks at $\mathrm{m} / \mathrm{z} 59$ and 403 , respectively, which are the products expected for hydrolysis of the bound $\mathrm{H}_{2} \mathrm{O}$ ligand during CID (reaction 6).

$\mathrm{CID}$ of $\left[\mathrm{UO}_{2}(\mathrm{aco})_{3}(\mathrm{CH} 3 \mathrm{OH})\right]^{2+}$ also leads primarily to $\left[\mathrm{UO}_{2}(\mathrm{aco})_{3}\right]^{2+}$ by simple elimination of $\mathrm{CH}_{3} \mathrm{OH}$. The methanolysis product, $\left[\mathrm{UO}_{2} \mathrm{OCH}_{3}(\text { aco })_{2}\right]^{+}$at $m / z 417$, is also observed and is presumably generated in a reaction similar to (6), and is significantly more abundant than the analogous hydroxide complex. This suggests that formation of the methoxide is favored over 
the hydroxide, which may be due to stronger binding of $\mathrm{CH}_{3} \mathrm{OH}$ to $\left[\mathrm{UO}_{2}(\mathrm{aco})_{3}\right]^{2+}$ and/or different fragmentation mechanisms.

Figure 5 shows the CID spectra for (a) $\left.\mathrm{UO}_{2}(\mathrm{aco})_{2}\left(\mathrm{H}_{2} \mathrm{O}\right)\right]^{2+},(\mathrm{b})\left[\mathrm{UO}_{2}(\mathrm{aco})_{2}\left(\mathrm{CH}_{3} \mathrm{OH}\right)\right]^{2+}$, (c) $\left[\mathrm{UO}_{2}(\mathrm{aco})_{2}\left(\mathrm{H}_{2} \mathrm{O}\right)_{2}\right]^{2+}$ and $(\mathrm{d})\left[\mathrm{UO}_{2}(\mathrm{aco})_{2}\left(\mathrm{H}_{2} \mathrm{O}\right)\left(\mathrm{CH}_{3} \mathrm{OH}\right)\right]^{2+}$. For each mono- and di-adduct to $\left[\mathrm{UO}_{2}(\mathrm{aco})_{2}\right]^{2+}$, hydrolysis and methanolysis is observed, with ligated $\left[\mathrm{UO}_{2} \mathrm{OH}\right]^{+}$or $\left[\mathrm{UO}_{2} \mathrm{OCH}_{3}\right]^{+}$ appearing as prominent, if not dominant, peaks in the product ion spectra. For $\left.\mathrm{UO}_{2}(\mathrm{aco})_{2}\left(\mathrm{H}_{2} \mathrm{O}\right)\right]^{2+}$ at $m / z 202$, direct $\mathrm{H}_{2} \mathrm{O}$ loss and formation of the $\left[\mathrm{UO}_{2} \mathrm{OH}(\mathrm{aco})\right]^{+} /(\mathrm{aco}+\mathrm{H})^{+}$pair occur with nearly equal probability. For $\left[\mathrm{UO}_{2}(\mathrm{aco})_{2}\left(\mathrm{CH}_{3} \mathrm{OH}\right)\right]^{2+}$ at $m / z 209$, direct $\mathrm{CH}_{3} \mathrm{OH}$ loss is not observed, and the product ion distribution is dominated by the methanolysis reaction to furnish $(\mathrm{aco}+\mathrm{H})^{+}$and $\left[\mathrm{UO}_{2} \mathrm{OCH}_{3}(\mathrm{aco})\right]^{+}$.

Hydrolysis is dominant for $\left[\mathrm{UO}_{2}(\mathrm{aco})_{2}\left(\mathrm{H}_{2} \mathrm{O}\right)_{2}\right]^{2+}$ at $m / z$ 211. Direct $\mathrm{H}_{2} \mathrm{O}$ elimination to generate the monohydrate at $\mathrm{m} / \mathrm{z} 202$ is a relatively minor pathway compared to formation of $\left[\mathrm{UO}_{2} \mathrm{OH}(\mathrm{aco})\left(\mathrm{H}_{2} \mathrm{O}\right)\right]^{+}$at $m / z$ 363. CID of $\left[\mathrm{UO}_{2}(\mathrm{aco})_{2}\left(\mathrm{H}_{2} \mathrm{O}\right)\left(\mathrm{CH}_{3} \mathrm{OH}\right)\right]^{2+}$ causes primarily the elimination of $\mathrm{H}_{2} \mathrm{O}$ to generate $\left[\mathrm{UO}_{2}(\mathrm{acO})_{2}\left(\mathrm{CH}_{3} \mathrm{OH}\right)\right]^{2+}$ at $m / z$ 209. This result in particular strongly supports the hypothesis that $\mathrm{CH}_{3} \mathrm{OH}$ interacts more strongly with $\mathrm{UO}_{2}{ }^{2+}$ than does $\mathrm{H}_{2} \mathrm{O}$, and that this influences in part the relative reaction tendency to generate methoxide products ions in charge reduction reactions. Stronger binding to a metal cation of $\mathrm{CH}_{3} \mathrm{OH}$ vs. $\mathrm{H}_{2} \mathrm{O}$ is in accord with the comparative gas phase basicities (GBs), which are derived from the proton affinities. The $\mathrm{GB}$ of $\mathrm{CH}_{3} \mathrm{OH}, 724 \mathrm{~kJ} / \mathrm{mol}$, is substantially higher than that of $\mathrm{H}_{2} \mathrm{O}, 660$ $\mathrm{kJ} / \mathrm{mol}^{38}$, which renders the former a better electron donor that binds more strongly to metal cations such as uranium in uranyl. For $\left[\mathrm{UO}_{2}(\mathrm{aco})_{2}\left(\mathrm{H}_{2} \mathrm{O}\right)\left(\mathrm{CH}_{3} \mathrm{OH}\right)\right]^{2+}$, the charge-reduction product generated in greatest abundance is $\left[\mathrm{UO}_{2} \mathrm{OCH}_{3}(\mathrm{aco})\left(\mathrm{H}_{2} \mathrm{O}\right)\right]^{+}$at $m / z$ 377. This composition assignment is preferred over $\left.\left[\mathrm{UO}_{2} \mathrm{OH}(\mathrm{aco}) \mathrm{CH}_{3} \mathrm{OH}\right)\right]^{+}$because the ion at $\mathrm{m} / \mathrm{z} 377$ dissociates to furnish $\left[\mathrm{UO}_{2} \mathrm{OCH}_{3}(\mathrm{aco})\right]^{+}$at $\mathrm{m} / z$ 359. This composition assignment is supported by the observed elimination of 58 mass units (neutral aco) to yield $\left[\mathrm{UO}_{2} \mathrm{OCH}_{3}\right]^{+}$in a subsequent CID step. The preferential elimination of protonated aco rather than $\mathrm{H}_{3} \mathrm{O}^{+}$, in concert with methoxide formation, is in accord with the higher proton affinity of aco $(812 \mathrm{~kJ} / \mathrm{mol})$ as compared with $\mathrm{H}_{2} \mathrm{O}$ $\left(691 \mathrm{~kJ} / \mathrm{mol}^{38}\right)$. 
The observations made here using CID of the $\mathrm{H}_{2} \mathrm{O}$ or $\mathrm{CH}_{3} \mathrm{OH}$ adducts support the conclusions drawn earlier regarding the formation of charge-reduced product ions via reactive collisions of $\left[\mathrm{UO}_{2}(\mathrm{aco})_{\mathrm{n}}\right]^{2+}$ with the respective neutrals. Indeed, subjecting the $\mathrm{H}_{2} \mathrm{O}$ adduct in particular to CID is akin to isolating the intermediate species likely formed during the fragmentation pathways that lead to aco-coordinated $\left[\mathrm{UO}_{2} \mathrm{OH}\right]^{+}$of $\left[\mathrm{UO}_{2} \mathrm{OCH}_{3}\right]^{+}$shown above. The general outcome of the CID reactions, and in particular the tendency to lose $\mathrm{H}_{2} \mathrm{O}$ or $\mathrm{CH}_{3} \mathrm{OH}$ or to undergo hydrolysis or methanolysis, is interesting and should motivate further DFT studies.

3.6 High-resolution mass measurements and infrared photodissociation of $\left[\mathrm{UO}_{2}(\mathrm{aco})_{n}\right]^{2+}, \mathrm{n}=3-5$

As noted above, one significant drawback to the use of the 3-D quadrupole ion trap in our earlier studies was that CID spectra from metal complexes were often dominated by $\mathrm{H}_{2} \mathrm{O}$ adducts or by hydrolysis products. One of the aims of the present study was to investigate the fragmentation of acetone-coordinated $\mathrm{UO}_{2}{ }^{2+}$ in a "cleaner" gas-phase environment. Use of an FT-ICR instrument provided both higher vacuum conditions (and presumably lower partial pressure of background $\mathrm{H}_{2} \mathrm{O}$ and $\mathrm{CH}_{3} \mathrm{OH}$ ) and the possibility to perform high-resolution and high-accuracy mass measurements to confirm compositions assignments for precursor and product ions. The desire to maintain high-vacuum conditions in the custom 9.4-T FT-ICR precluded the examination of fragmentation by collisional activation. Instead, ion dissociation by fixed wavelength $(10.6 \mu \mathrm{m})$ IRMPD was investigated.

The most abundant peak in the FT-ICR spectrum had a measured $m / z$ of 280.1254, compared a calculated value of 280.1244 (3.6 ppm error) expected for a molecular formula of $\mathrm{UO}_{7} \mathrm{C}_{15} \mathrm{H}_{30}$ and the composition assignment of $\left[\mathrm{UO}_{2}(\mathrm{aco})_{5}\right]^{2+}$. The product ion spectra generated by photodissociation of $\left[\mathrm{UO}_{2}(\mathrm{aco})_{5}\right]^{2+},\left[\mathrm{UO}_{2}(\mathrm{aco})_{4}\right]^{2+}$ and $\left[\mathrm{UO}_{2}(\mathrm{aco})_{3}\right]^{2+}$ are shown in Figure $6 \mathrm{a}, 6 \mathrm{~b}$ and $6 \mathrm{c}$, respectively. The IRMPD spectra for $\left[\mathrm{UO}_{2}(\mathrm{aco})_{5}\right]^{2+}$ and $\left[\mathrm{UO}_{2}(\mathrm{aco})_{4}\right]^{2+}$ were collected by direct isolation of the respective species from the ESI source. The IRMPD spectrum of $\left[\mathrm{UO}_{2}(\mathrm{aco})_{3}\right]^{2+}$ was collected in an $\mathrm{MS}^{3}$ experiment following the initial photodissociation of $\left[\mathrm{UO}_{2}(\mathrm{aco})_{5}\right]^{2+}$. Measured and calculated exact masses for the respective precursor and product ions are provided in Table 1. 
The most abundant photodissociation product generated from $\left[\mathrm{UO}_{2}(\mathrm{aco})_{5}\right]^{2+}$ had a measured $\mathrm{m} / \mathrm{z}$ value of 251.1037, which is within $1 \mathrm{ppm}$ of the calculated $\mathrm{m} / \mathrm{z}$ of 251.1035 and the molecular formula of $\mathrm{UO}_{6} \mathrm{C}_{12} \mathrm{H}_{24}$ for $\left[\mathrm{UO}_{2}(\mathrm{aco})_{4}\right]^{2+}$. Two other product ions were observed at relative intensities greater than $1 \%$. The first had a measured $m / z$ value of 327.0748 , compared to a calculated $\mathrm{m} / \mathrm{z}$ value of 327.0741 for the molecular formula $\mathrm{UO}_{3} \mathrm{C}_{3} \mathrm{H}_{5}{ }^{+}$(2.1 ppm error). The accurate mass measurement supports the assignment made in the LIT experiments of $\mathrm{UO}_{2}{ }^{2+}$ coordinated by a deprotonated acetone ligand $\left(\left[\mathrm{UO}_{2}(\mathrm{aco}-\mathrm{H})\right]^{+}\right)$. The second product ion has a measured $\mathrm{m} / \mathrm{z}$ value of 385.1176 , which agrees well with the calculated value of 385.1159 (4.4 ppm error) and a molecular formula of $\mathrm{UO}_{4} \mathrm{C}_{6} \mathrm{H}_{11}$. In this case, the accurate mass measurement supports the composition assignment of $\left[\mathrm{UO}_{2}(\mathrm{aco}-\mathrm{H})(\mathrm{aco})\right]^{+}$. As for the LIT experiments, we suggest that the dissociation pathway that involves elimination of presumed intra-complex proton transfer, elimination of acetone ligands and coordination of $\mathrm{UO}_{2}{ }^{2+}$ of deprotonated acetone.

The dominant product ion generated by photodissociation of $\left[\mathrm{UO}_{2}(\mathrm{aco})_{4}\right]^{2+}$ was $\left[\mathrm{UO}_{2}(\mathrm{aco})_{3}\right]^{2+}$ at a measured $\mathrm{m} / z$ value of 222.0829 , which compares well to the calculated value of 222.0825 (1.8 ppm error) for a molecular formula of $\mathrm{UO}_{5} \mathrm{C}_{9} \mathrm{H}_{18}$. As for the $\left[\mathrm{UO}_{2}(\mathrm{aco})_{5}\right]^{2+}$ precursor, product ions at nominal $\mathrm{m} / \mathrm{z} 327$ and 385 were also observed. Other products generated by IRMPD included species with measured $m / z$ values of 270.0419, 287.0450, 299.0452 and 299.0812 .

The latter two species, at $m / z 299.0452$ and 299.0812, were also observed during photodissociation of the $\left[\mathrm{UO}_{2}(\mathrm{aco})_{3}\right]^{2+}$ precursor and are discussed below. The measured value for the species at nominal $\mathrm{m} / \mathrm{z} 270$, agrees well with a calculated value of $270.0400(7.0 \mathrm{ppm}$ error) for the molecular formula $\mathrm{UO}_{2}$. The product ion is thus generated by elimination of 3 neutral acetone ligands, oxidation of the $4^{\text {th }}$ aco ligand, and reduction of the uranyl dication to $\mathrm{UO}_{2}{ }^{+}$. As noted above, similar results were observed during the CID experiments on the LIT when the aco coordination number was reduced to 1.

Appearance of an ion with nominal $\mathrm{m} / \mathrm{z}$ of 287 in the photodissociation spectrum of $\left[\mathrm{UO}_{2}(\mathrm{aco})_{4}\right]^{2+}$ was surprising. The accurate $\mathrm{m} / \mathrm{z}$ measurement for the ion was 287.0450, which agrees well with the calculated value of 287.0428 (7.7 ppm error), a molecular formula of $\mathrm{UO}_{3} \mathrm{H}$, 
and composition assignment of $\mathrm{UO}_{2} \mathrm{OH}^{+}$. In the LIT experiments, we assume that $\mathrm{UO}_{2} \mathrm{OH}^{+}$is generated primarily by energetic collisions with background $\mathrm{H}_{2} \mathrm{O}$. However, the partial pressure of $\mathrm{H}_{2} \mathrm{O}$ in the FT-ICR is significantly lower and an alternative pathway may involve dissociation through an enol-intermediate, with retention of hydroxide by the $\mathrm{UO}_{2}{ }^{2+}$ unit and elimination of $\mathrm{CH}_{2}=\mathrm{C}-\mathrm{CH}_{3}{ }^{+}$. As noted earlier, a potential pathway for generation of $\mathrm{UO}_{2} \mathrm{OH}^{+}$by decomposition of deprotonated acetone during $\mathrm{CID}$ of $\left[\mathrm{UO}_{2}(\mathrm{aco}-\mathrm{H})\right]^{+}$was suggested based on the isotope labeling experiments. In the IR photodissociation experiments conducted with the FT-ICR instrument, $\mathrm{UO}_{2} \mathrm{OH}^{+}$may be generated by the fragmentation of energetic $\left[\mathrm{UO}_{2}(\text { aco-H})\right]^{+}$ resulting from photodissociation of $\left[\mathrm{UO}_{2}(\mathrm{aco})_{4}\right]^{2+}$.

The photodissociation spectrum of $\left[\mathrm{UO}_{2}(\mathrm{aco})_{3}\right]^{2+}$ (figure $6 \mathrm{c}$ ) contains the same product ions observed following photodissociation of $\left[\mathrm{UO}_{2}(\mathrm{aco})_{4}\right]^{2+}$, along with a product with (measured) $\mathrm{m} / \mathrm{z}$ value of 193.0619. This measured value agrees well with a calculated value of 193.0616 (1.6 ppm error) and a molecular formula of $\mathrm{UO}_{4} \mathrm{C}_{6} \mathrm{H}_{12}$ (consistent with the assignment of $\left.\left[\mathrm{UO}_{2}(\mathrm{aco})_{2}\right]^{2+}\right)$. As noted above, product ions were also observed at $\mathrm{m} / \mathrm{z} 299.0452$ and 299.0812. Based on the accurate mass measurement (Table 1), the ions have molecular formulae of $\mathrm{UO}_{3} \mathrm{CH}$ and $\mathrm{UO}_{2} \mathrm{C}_{2} \mathrm{H}_{5}$, respectively. The former appears to involve conversion of deprotonated acetone to $\mathrm{HCO}$ through the elimination of $\mathrm{CH}_{2}=\mathrm{CH}_{2}$, as observed in the LIT experiments following $\mathrm{CID}$ of $\left[\mathrm{UO}_{2}(\mathrm{aco}-\mathrm{H})\right]^{+}$. The second likely involves conversion of deprotonated acetone to $\mathrm{CO}$ and $\mathrm{CH}_{3}-\mathrm{CH}_{2}$. The high resolution/high accuracy measurements therefore support the dissociation pathways for $\left[\mathrm{UO}_{2}(\mathrm{aco}-\mathrm{H})\right]^{+}$revealed in the LIT experiments. This also provides new evidence of more than one product at nominal $\mathrm{m} / \mathrm{z} 299$, indicating at least two fragmentation mechanisms are of relevance here. The mechanisms by which these conversions occur are not clear and would benefit from detailed quantum mechanical calculations.

\subsection{Infrared photodissociation in the linear ion trap MS}

As noted above, the LIT at Duquesne has been modified to allow IR photodissociation experiments. We are therefore able to make a comparison of photodissociation of the $\left[\mathrm{UO}_{2}(\mathrm{aco}) \mathrm{n}\right]^{2+}$ precursor ions at $10.6 \mu \mathrm{m}$ in the FT-ICR and LIT instruments. In addition, the use 
of IRMPD with both types of mass spectrometers allows for further investigation of the potential role(s) background $\mathrm{H}_{2} \mathrm{O}$ may play in the appearance of product ions and product ion distributions. As noted earlier, one main goal of this study was to determine the intrinsic fragmentation pathways for the acetone-coordinated uranyl ion, free as much as possible from influence by background $\mathrm{H}_{2} \mathrm{O}$.

Because IRMPD data using the high-resolution FT-ICR instrument could only be collected for $\left[\mathrm{UO}_{2}(\mathrm{aco})_{5}\right]^{2+},\left[\mathrm{UO}_{2}(\mathrm{aco})_{4}\right]^{2+}$ and $\left[\mathrm{UO}_{2}(\mathrm{aco})_{3}\right]^{2+}$, only these species were investigated using the LIT instrument and the photodissociation spectra for the respective ions are shown in Figure 7. In the LIT experiments, each photodissociation spectrum was collected by isolating the precursor directly from the ESI source rather than in an $\mathrm{MS}^{\mathrm{n}}$ approach.

As in the CID experiments, IR photodissociation of $\left[\mathrm{UO}_{2}(\mathrm{aco})_{5}\right]^{2+}$ (Figure $\left.7 \mathrm{a}\right)$ in the LIT produced only $\left[\mathrm{UO}_{2}(\mathrm{aco})_{4}\right]^{2+}$ at $\mathrm{m} / z$ 251. Unlike the FT-ICR experiments, generation of $\left[\mathrm{UO}_{2}(\right.$ aco$\mathrm{H})]^{+}$and $\left[\mathrm{UO}_{2}(\text { aco- } \mathrm{H})(\text { aco })\right]^{+}$at $m / z 327$ and 385, respectively, was not observed. A likely explanation for this observation is the differences in irradiation times and intensities that were used for IRMPD in the LIT and FT-ICR instruments (ca. $30 \mathrm{~ms}$ for the former and $200 \mathrm{~ms}$ for the latter), and potential differences in the overlap between the IR laser and the ion cloud.

IR photodissociation of $\left[\mathrm{UO}_{2}(\mathrm{aco})_{4}\right]^{2+}$ in the LIT (Figure $7 \mathrm{~b}$ ) produced primarily $\left[\mathrm{UO}_{2}(\mathrm{aco})_{3}\right]^{2+}$ and $m / z 222$, with $\left[\mathrm{UO}_{2}(\mathrm{aco})_{2}\right]^{2+}$ and $\mathrm{UO}_{2}{ }^{+}$, at $m / z 193$ and 270, respectively, also observed at relative intensities above $1 \%$. Interestingly, no $\mathrm{H}_{2} \mathrm{O}$ adduct to $\left[\mathrm{UO}_{2}(\mathrm{aco})_{3}\right]^{2+}$, i.e. $\left[\mathrm{UO}_{2}(\mathrm{aco})_{3}\left(\mathrm{H}_{2} \mathrm{O}\right)\right]^{2+}$ at $m / z 237$, was observed. The adduct was observed in the product ion spectrum when $\left[\mathrm{UO}_{2}(\mathrm{aco})_{4}\right]^{2+}$ was subjected to $\mathrm{CID}$ (Figure $2 \mathrm{a}$ ), albeit at less than $5 \%$ relative intensity.

As in the FT-ICR experiments, IRMPD of $\left[\mathrm{UO}_{2}(\mathrm{aco})_{3}\right]^{2+}$ at $\mathrm{m} / z 222$ (Figure $6 \mathrm{c}$ ) in the LIT generated product ions at $\mathrm{m} / z 193\left(\left[\mathrm{UO}_{2}(\mathrm{aco})_{2}\right]^{+}\right)$and $270\left(\mathrm{UO}_{2}{ }^{+}\right) . \mathrm{UO}_{2} \mathrm{OH}^{+}$at $\mathrm{m} / z 287$ was also observed, and is the only species generated by IRMPD in the LIT that contains hydroxide. Despite the higher levels of $\mathrm{H}_{2} \mathrm{O}$ in the LIT (compared to the FT-ICR), the photodissociation spectrum appears to contain the same product ions generated in the cleaner gas-phase environment (the FT-ICR). It may therefore be that $\mathrm{UO}_{2} \mathrm{OH}^{+}$is generated by the fragmentation of energetic $\left[\mathrm{UO}_{2}(\text { aco-H) }]^{+}\right.$resulting from, in this case, initial photodissociation of $\left[\mathrm{UO}_{2}(\operatorname{aco})_{3}\right]^{2+}$. 
Most interesting was the appearance of peaks at $m / z 299$ and 327, which match those observed in the FT-ICR experiments. The resolution of the LIT is not sufficiently high to resolve the peak at nominal $\mathrm{m} / \mathrm{z} 299$ into the individual ions suggested by both the high-resolution measurements in the FT-ICR or the isotope labeling study using CID. However, the results here show that the interesting dissociation channels are also activated by IRMPD in the LIT instrument.

\subsection{CONCLUSIONS}

To summarize, fragmentation of acetone-coordinated uranyl ion, $\left[\mathrm{UO}_{2}(\text { aco })_{n}\right]^{2+}(\mathrm{n}=1-5)$, was revisited here using a LIT mass spectrometer in which the level of background $\mathrm{H}_{2} \mathrm{O}$ is significantly lower than in 3-D ion traps used in previous studies. ${ }^{13,14,22}$ The lower apparent partial pressure of $\mathrm{H}_{2} \mathrm{O}$ in the LIT provided access to the fragmentation behavior of each complex ion. For $n=3-5$, direct elimination of aco ligands is the favored fragmentation pathway. For $\mathrm{n}=1$ and 2, charge reduction reactions are dominant: for $\left[\mathrm{UO}_{2}(\mathrm{aco})_{2}\right]^{2+}$, the most abundant product ion is $\left[\mathrm{UO}_{2}(\mathrm{aco})\right]^{+}$while $\mathrm{UO}_{2}{ }^{+}$is observed following $\mathrm{CID}$ of $\left[\mathrm{UO}_{2}(\mathrm{aco})\right]^{2+}$. Minor peaks corresponding to ligated $\mathrm{UO}_{2} \mathrm{OH}^{+}$are also observed.

We also investigated the $\mathrm{CID}$ of $\mathrm{H}_{2} \mathrm{O}$ and $\mathrm{CH}_{3} \mathrm{OH}$ adducts to $\left[\mathrm{UO}_{2}(\mathrm{aco})_{3}\right]^{2+}$, $\left[\mathrm{UO}_{2}(\mathrm{aco})_{2}\right]^{2+}$ and $\left[\mathrm{UO}_{2}(\mathrm{aco})\right]^{2+}$. CID of $\left[\mathrm{UO}_{2}(\mathrm{aco})_{3}\left(\mathrm{H}_{2} \mathrm{O}\right)\right]^{2+}$ and $\left[\mathrm{UO}_{2}(\mathrm{aco})_{3}\left(\mathrm{CH}_{3} \mathrm{OH}\right)\right]^{2+}$ leads primarily to formation of $\left[\mathrm{UO}_{2}(\mathrm{aco})_{3}\right]^{2+}$ by simple elimination of the solvent molecule. Hydrolysis and methanolysis became the dominant pathways for adducts to $\left[\mathrm{UO}_{2}(\mathrm{aco})_{2}\right]^{2+}$ that contained 1 or 2 $\mathrm{H}_{2} \mathrm{O}$ or $\mathrm{CH}_{3} \mathrm{OH}$ ligands. The CID behavior of the adducts both supports the conclusions drawn earlier regarding the formation of charge-reduced product ions via reactive collisions of $\left[\mathrm{UO}_{2}(\mathrm{aco}) \mathrm{n}\right]^{2+}$ with the respective neutrals and the hypothesis that 3 aco ligands are necessary to stabilize ligand addition versus charge reduction.

The IRMPD experiments in the FT-ICR yielded highly accurate mass measurements that strongly support composition assignments, and shed light on dissociation reactions in a gasphase environment that is free of $\mathrm{H}_{2} \mathrm{O}$. For $\left[\mathrm{UO}_{2}(\mathrm{aco})_{n}\right]^{2+}, \mathrm{n}=3-5$, the primary photodissociation channel is direct aco elimination, along with charge-reduction pathways that involve intra- 
complex proton transfer and formation of species that contain enolate ligands. Similar pathways are observed for IMRPD measurements in the LIT.

The IRMPD investigations, particularly those in the FT-ICR instrument, along with CID using deuterium labeled acetone, helped identify new reaction pathways for decomposition of $\left[\mathrm{UO}_{2}(\text { aco-H })\right]^{+}$that involve elimination of 28 mass units. The isotope labeling studies suggested that loss of 28 mass units from $\left[\mathrm{UO}_{2}(\mathrm{aco}-\mathrm{H})\right]^{+}$involves elimination of either $\mathrm{CO}$ or $\mathrm{CH}_{2}=\mathrm{CH}_{2}$. These two pathways were confirmed by high-accuracy mass measurements in the FT-ICR instrument. While the mechanisms by which $\mathrm{CO}$ or $\mathrm{CH}_{2}=\mathrm{CH}_{2}$ are eliminated are not clear, the reactions further illustrate the rich chemistry of these complexes that may be accessed in the relatively clean gas-phase environment of the LIT instrument.

\subsection{ACKNOWLEDGEMENTS}

MVS and TAC acknowledge support for this work in the form of start-up funds from the Bayer School of Natural and Environmental Sciences and Duquesne University. Laboratory space renovation at Duquesne University was made possible through support by the National Science Foundation (NSF) through grant CHE-0963450. Portions of this work were supported by the NSF Division of Materials Research through DMR-11-57490, and the State of Florida. BJB thanks the University of Missouri-St. Louis for start-up funds. JKG was supported by the U.S. Department of Energy, Office of Basic Energy Sciences, Heavy Element Chemistry, at LBNL under Contract No. DE-AC02-05CH11231.

\section{SUPPORTING INFORMATION}

A schematic of the modified linear ion trap, and CID spectra of the $\mathrm{m} / \mathrm{z} 179$ product derived from fragmentation of $\left[\mathrm{UO}_{2}(\mathrm{aco})_{2}\right]^{2+}$, and the $\mathrm{m} / \mathrm{z} 183$ product derived from fragmentation of $\left[\mathrm{UO}_{2}\left(\mathrm{~d}_{6}-\mathrm{aco}\right)_{2}\right]^{2+}$ are provided as Figures S1 and S2, respectively, of the supporting information. 


\section{LITERATURE CITED}

(1) H. H. Cornehl, C. Heinemann, J. Marçalo, A. Pires de Matos, H. Schwarz, The "bare" uranyl(2+) ion, $\mathrm{UO}_{2}^{2+}$. Angew. Chem., Int. Ed. Engl. 1996, 35, 891-894.

(2) J. K. Gibson, R. G. Haire, M. Santos, J. Marçalo, A. Pires de Matos, Oxidation studies of dipositive actinide ions, $\mathrm{An}^{2+}(\mathrm{An}=\mathrm{Th}, \mathrm{U}, \mathrm{Np}, \mathrm{Pu}, \mathrm{Am})$ in the gas phase: synthesis and characterization of the isolated uranyl, neptunyl, and plutonyl ions $\mathrm{UO}_{2}{ }^{2+}(\mathrm{g}), \mathrm{NpO}_{2}{ }^{2+}(\mathrm{g})$, and $\mathrm{PuO}_{2}{ }^{2+}(\mathrm{g})$. J. Phys. Chem. A 2005, 109, 2768-2781.

(3) G. R. Agnes, G. Horlick, Electrospray mass spectrometry as a technique for elemental analysis: preliminary results. Appl. Spectrosc. 1992, 46, 401-406.

(4) N. G. Tsierkezos, J. Roithova, D. Schroder, M. Oncak, P. Slavicek, Can electrospray mass spectrometry quantitatively probe speciation? Hydrolysis of uranyl nitrate studied by gas-phase methods. Inorg. Chem. 2009, 48, 6287-6296.

(5) G. S. Groenewold, A. K. Gianotto, K. C. Cossel, M. J. Van Stipdonk, D. T. Moore, N. Polfer, J. Oomens, W. A. de Jong, L. Visscher, Vibrational spectroscopy of mass-selected $\left[\mathrm{UO}_{2}(\text { ligand })_{\mathrm{n}}\right]^{2+}$ complexes in the gas phase: comparison with theory. J. Am. Chem. Soc. 2006, $128,4802-4813$.

(6) G. S. Groenewold, J. Oomens, W. A. de Jong, G. L. Gresham, M. E. Mcllwain, M. J. Van Stipdonk, Vibrational spectroscopy of anionic nitrate complexes of $\mathrm{UO}_{2}{ }^{2+}$ and $\mathrm{Eu}^{3+}$ isolated in the gas phase. Phys. Chem. Chem. Phys. 2008, 10, 1192-1202.

(7) G. S. Groenewold, M. J. Van Stipdonk, W. A. de Jong, J. Oomens, G. L. Gresham, M. E. McIlwain, D. Gao, B. Siboulet, L. Visscher, M. Kullman, N. Polfer, Infrared spectroscopy of dioxouranium(V) complexes with solvent molecules: effect of reduction. ChemPhysChem 2008, 9, 1278-1285.

(8) G. S. Groenewold,; M. J. van Stipdonk,; J. Oomens,; W. A. de Jong,; M. E. Mcllwain, The gas-phase bis-uranyl nitrate complex $\left[\left(\mathrm{UO}_{2}\right)_{2}\left(\mathrm{NO}_{3}\right)_{5}\right]:$ : Infrared spectrum and structure. Int. J. Mass Spectrom. 2011, 308, 175-180.

(9) S. Pasilis, Á. Somogyi, K. Herrmann, J. E. Pemberton, Ions generated from uranyl nitrate solutions by electrospray ionization (ESI) and detected with fourier transform ion-cyclotron resonance (FT-ICR) mass spectrometry. J. Am. Soc. Mass Spectrom. 2006, 17, 230-240.

(10) S. P. Pasilis, J. E. Pemberton, Speciation and coordination chemistry of uranyl(VI)-citrate complexes in aqueous solution. Inorg. Chem. 2003, 42, 6793-6800.

(11) D. Rios, G. Schoendorff, M. J. Van Stipdonk, M. S. Gordon, T. L. Windus, J. K. Gibson, W. A. de Jong, Roles of acetone and diacetone alcohol in coordination and dissociation reactions of uranyl complexes. Inorg. Chem. 2012, 51, 12768-12775. 
(12) G. Schoendorff, W. A. de Jong, M. J. Van Stipdonk, J. K. Gibson, D. Rios, M. S. Gordon, T. L. Windus, On the formation of "hypercoordinated" uranyl complexes. Inorg. Chem. 2011, 50, 8490-8493.

(13) M. J. Van Stipdonk, W. Chien, V. Anbalagan, K. Bulleigh, D. Hanna, G. S. Groenewold, Gas-phase complexes containing the uranyl ion and acetone. J. Phys. Chem. A 2004, 108, 1044810457.

(14) M. J. Van Stipdonk, W. Chien, K. Bulleigh, Q. Wu, G. S. Groenewold, Gas-phase uranylnitrile complex ions. J. Phys. Chem. A 2006, 110, 959-970.

(15) D. Das, S. Kannan, D. K. Maity, M. G. B. Drew, Steric effects on uranyl complexation: synthetic, structural, and theoretical studies of carbamoyl pyrazole compounds of the Uranyl(VI) Ion. Inorg. Chem. 2012, 51, 4869-4876.

(16) P. D. Dau, J. Su, H.-T. Liu, D.-L. Huang, J. Li, L.-S. Wang, Photoelectron spectroscopy and the electronic structure of the uranyl tetrachloride dianion: $\mathrm{UO}_{2} \mathrm{Cl}_{4}{ }^{2-}$. J. Chem. Phys. 2012, $137,064315$.

(17) P. D. Dau, J. Su, H.-T. Liu, J.-B. Liu, D.-L. Huang, J. Li, L.-S. Wang, Observation and investigation of the uranyl tetrafluoride dianion $\left(\mathrm{UO}_{2} \mathrm{~F}_{4}{ }^{2-}\right)$ and its solvation complexes with water and acetonitrile. Chem. Sci. 2012, 3, 1137-1146.

(18) W.-L. Li, J. Su, T. Jian, G. V. Lopez, H.-S. Hu, G.-J. Cao, J. Li, L.-S. Wang, Strong electron correlation in $\mathrm{UO}_{2}^{-}$: A photoelectron spectroscopy and relativistic quantum chemistry study. $\mathrm{J}$. Chem. Phys. 2014, 140, 094306.

(19) J. Su, P. D Dau, Y.-H. Qiu, H.-T. Liu, C.-F. Xu, D.-L. Huang, L.-S. Wang, J. Li, Probing the Electronic Structure and Chemical Bonding in Tricoordinate Uranyl Complexes $\mathrm{UO}_{2} \mathrm{X}_{3^{-}}(\mathrm{X}=\mathrm{F}$, $\mathrm{Cl}, \mathrm{Br}, \mathrm{I})$ : Competition between Coulomb Repulsion and U-X Bonding. Inorg. Chem. 2013, 52, 6617-6626.

(20) D. Rios, M. C. Michelini, A. F. Lucena, J. Marçalo, J. K. Gibson, On the origins of faster oxo exchange for uranyl(V) versus plutonyl(V). J. Am. Chem. Soc. 2012, 134, 15488-15496.

(21) D. Rios, P. X. Rutkowski, D. K. Shuh, T. H. Bray, J. K. Gibson, M. J. Van Stipdonk, Electron transfer dissociation of dipositive uranyl and plutonyl coordination complexes. J. Mass Spectrom. 2011, 46, 1247-1254.

(22) D. Rios, P. X. Rutkowski, M. J. Van Stipdonk, J. K. Gibson, Gas-phase coordination complexes of dipositive plutonyl, $\mathrm{PuO}_{2}{ }^{2+}$ : chemical diversity across the actinyl series. Inorg. Chem. 2011, 50, 4781-4790. 
(23) P. X. Rutkowski,; D. Rios,; J. K. Gibson,; M. J. Van Stipdonk, Gas-phase coordination complexes of $\mathrm{UVI}_{2}{ }^{2+}, \mathrm{Np}^{\mathrm{VI}} \mathrm{O}_{2}{ }^{2+}$, and $\mathrm{Pu}^{\mathrm{VI}} \mathrm{O}_{2}{ }^{2+}$ with dimethylformamide. J. Am. Soc. Mass Spectrom. 2011, 22, 2042-2048.

(24) M. J. Van Stipdonk, M. C. Michelini, A. Plaviak, D. Martin, J. K. Gibson, Formation of bare $\mathrm{UO}_{2}{ }^{2+}$ and $\mathrm{NUO}^{+}$by fragmentation of gas-phase uranyl-acetonitrile complexes. J. Phys. Chem. A 2014, 118, 7838-7846.

(25) C. Heinemann, H. Schwarz, $\mathrm{NUO}^{+}$, A new species isoelectronic to the Uranyl dication $\mathrm{UO}_{2}{ }^{2+}$. Chem. - Eur. J. 1995, 1, 7-11.

(26) N. K. Kaiser, J. P. Quinn, G. T. Blakney, C. L. Hendrickson, A. G. Marshall, A Novel 9.4 Tesla FT-ICR Mass Spectrometer With Improved Sensitivity, Mass Resolution and Mass Range. J. Am. Soc. Mass Spectrom. 2011, 22, 1343-1351.

(27) M. R. Emmett, F. M. White, C. L. Hendrickson, D. D.-H. Shi, A. G. Marshall, Application of Micro-electrospray Liquid Chromatography Techniques to FT-ICR MS To Enable High Sensitivity Biological Analyis. J. Am. Soc. Mass Spectrom. 1998, 9, 333-340.

(28) M. R. Emmett, R. M. Caprioli, Micro-electrospray Mass Spectrometry: Ultra-highsensitivity Analysis of Peptides and Proteins. J. Am. Soc. Mass Spectrom. 1994, 5, 605-613.

(29) N. K. Kaiser, J. J. Savory, J. P. Quinn, A. M. McKenna, C. J. Hendrickson, A. G. Marshall, Electrically Compensated Fourier Transform Ion Cyclotron Resonance Cell for Complex Mixture Analysis. Anal. Chem. 2011, 83, 6907-6910.

(30) A. G. Marshall, T.-C. L Wang, T. L. Ricca, Tailored Excitation for Fourier Transform Ion Cyclotron Resonance Mass Spectrometry. J. Am. Chem. Soc. 1985, 107, 7893-7897.

(31) S. H. Guan, A. G. Marshall, Stored Waveform Inverse Fourier Transform (SWIFT) Ion Excitation in Trapped-ion Mass Spectrometry: Theory and Applications. Int. J. Mass Spectrom. Ion Processes, 1996, 158, 5-37.

(32) B. J. Bythell, C. L. Hendrickson, A. G. Marshall, Relative Stability of Peptide Sequence Ions Generated by Tandem Mass Spectrometry. J. Am. Soc. Mass Spectrom. 2012, 23, 644-654.

(33) G. T. Blakney, C. L. Hendrickson, A. G. Marshall, Predator Data Station: A Fast Data Acquisition System for Advanced FT-ICR MS Experiments. Int J. Mass Spectrom. 2011, 306, 246252.

(34) A. G. Marshall, F. R. Verdun, Fourier Transforms in NMR, Optical and Mass Spectrometry: A Users Handbook, Elsevier: Amsterdam, pp. 80-93 (1990).

(35) E. B. J. Ledford, D. L. Rempel, M. L. Gross. Space Charge Effects in Fourier Tranform Mass Spectrometry. II. Mass-Calibration. Anal. Chem. 1984, 56, 2744-2748. 
(36) J. Wu, D. Liu, J.-D. Zhou, F. Hagelberg, S. S. Park, A. A. Shvartsburg, Chemistry in acetone complexes of metal dications: a remarkable ethylene production pathway. J. Phys. Chem. A 2007, 111, 4748-4758.

(37) J. Marçalo, J. K. Gibson, Gas-phase energetics of actinide oxides: an assessment of neutral and cationic monoxides and dioxides from thorium to curium. J. Phys. Chem. A 2009, 113, 12599-12606.

(38) S. G. Lias, J. E. Bartmess, J. F. Liebman, J. L. Holmes, R. D. Levin, W. G. Mallard, Gasphase ion and neutral thermochemisty. J. Phys. Chem. Ref. Data 1988, 17, 1-861.

(39) K. G. Spears, G. C. Fehsenfeld, M. McFarland, E. E. Ferguson, Partial charge-transfer reactions at thermal energies. J. Chem. Phys. 1972, 56, 2562-2566.

(40) C. M. Leavitt, V. S. Bryantsev, W. A. de Jong, M. S. Diallo, W. A. Goddard III, G. S. Groenewold and M. J. Van Stipdonk, Addition of $\mathrm{H}_{2} \mathrm{O}$ and $\mathrm{O}_{2}$ to Acetone and Dimethylsulfoxide Ligated Uranyl(V) Dioxocations, J. Phys. Chem. A, 2009, 113, 2350-2358. 


\section{LIST OF FIGURES AND TABLES}

Figure 1. Electrospray ionization mass spectrum generated from uranyl nitrate hexahydate dissolved in $\mathrm{H}_{2} \mathrm{O}$ with $5 \%$ by volume of aco. The insets show high-resolution scans centered on $\left[\mathrm{UO}_{2}(\mathrm{aco})_{4}\right]^{2+}$ and $\left[\mathrm{UO}_{2}(\mathrm{aco})_{5}\right]^{2+}$.

Figure 2. Collision induced dissociation spectra generated from uranyl-aco complex ions: (a) fragmentation of $\left[\mathrm{UO}_{2}(\mathrm{aco})_{4}\right]^{2+}$, (b) fragmentation of $\left[\mathrm{UO}_{2}(\mathrm{aco})_{3}\right]^{2+}$, (c) fragmentation of $\left[\mathrm{UO}_{2}(\mathrm{aco})_{2}\right]^{2+}$, and (d) fragmentation of $\left[\mathrm{UO}_{2}(\mathrm{aco})\right]^{2+}$. Asterisks in each spectrum indicate adducts $\left(\mathrm{H}_{2} \mathrm{O}\right.$ and/or $\left.\mathrm{CH}_{3} \mathrm{OH}\right)$ generated by ionmolecule reactions. The circle and arrow legends identifies the sequence of CID stages that produces a given product in spectra. Filled circles indicate the ions specifically isolated for collisional activation. Open circles symbolize product ions generated in the last CID step in a given sequence.

Figure 3. Collision induced dissociation spectra generated from singly charged uranyl-aco complex ions: (a) fragmentation of $\left[\mathrm{UO}_{2}(\mathrm{aco}-\mathrm{H})(\mathrm{aco})\right]^{+}$at $\mathrm{m} / \mathrm{z} 385$, (b) fragmentation of $\left[\mathrm{UO}_{2}(\mathrm{aco}-\mathrm{H})\right]^{+}$at $m / z 327$ (c) fragmentation of $\left[\mathrm{UO}_{2}\left(\mathrm{~d}_{6} \mathrm{aco}-\mathrm{D}\right)\right]^{+}$at $m / z$ 332. Asterisks in each spectrum indicate adducts $\left(\mathrm{H}_{2} \mathrm{O}\right.$ and/or $\left.\mathrm{CH}_{3} \mathrm{OH}\right)$ generated by ion-molecule reactions. The circle and arrow legends identifies the sequence of CID stages that produces a given product in spectra. Filled circles indicate the ions specifically isolated for collisional activation. Open circles symbolize product ions generated in the last CID step in a given sequence.

Figure 4. Collision induced dissociation spectra generated from $\mathrm{H}_{2} \mathrm{O}$ and $\mathrm{CH}_{3} \mathrm{OH}$ adducts of $\left[\mathrm{UO}_{2}(\mathrm{aco})_{3}\right]^{2+}$ : (a) CID of (a) $\left[\mathrm{UO}_{2}(\mathrm{aco})_{3}\left(\mathrm{H}_{2} \mathrm{O}\right)\right]^{2+}$ and (b) $\left[\mathrm{UO}_{2}(\mathrm{aco})_{3}\left(\mathrm{CH}_{3} \mathrm{OH}\right)\right]^{2+}$. The circle and arrow legends identifies the sequence of CID stages that produces a given product in spectra. Partially shaded circles indicate species isolated but not subjected to collisional activation. Filled circles indicate the ions specifically isolated for collisional activation. Open circles symbolize product ions generated in the last CID step in a given sequence.

Figure 5. Collision induced dissociation spectra generated from $\mathrm{H}_{2} \mathrm{O}$ and $\mathrm{CH}_{3} \mathrm{OH}$ adducts of $\left[\mathrm{UO}_{2}(\mathrm{aco})_{2}\right]^{2+}$ : (a) $\left.\mathrm{UO}_{2}(\mathrm{aco})_{2}\left(\mathrm{H}_{2} \mathrm{O}\right)\right]^{2+}$, (b) $\left[\mathrm{UO}_{2}(\mathrm{aco})_{2}\left(\mathrm{CH}_{3} \mathrm{OH}\right)\right]^{2+}$, (c) $\left[\mathrm{UO}_{2}(\mathrm{aco})_{2}\left(\mathrm{H}_{2} \mathrm{O}\right)_{2}\right]^{2+}$ and $(\mathrm{d})\left[\mathrm{UO}_{2}(\mathrm{aco})_{2}\left(\mathrm{H}_{2} \mathrm{O}\right)\left(\mathrm{CH}_{3} \mathrm{OH}\right)\right]^{2+}$. The circle and arrow legends identifies the sequence of CID stages that produces a given product in spectra. Partially shaded circles indicate species isolated but not subjected to 
collisional activation. Filled circles indicate the ions specifically isolated for collisional activation. Open circles symbolize product ions generated in the last CID step in a given sequence.

Figure 6. IR photodissociation spectra generated from uranyl-aco complex ions: (a) fragmentation of $\left[\mathrm{UO}_{2}(\mathrm{aco})_{5}\right]^{2+}$, (b) fragmentation of $\left[\mathrm{UO}_{2}(\mathrm{aco})_{4}\right]^{2+}$ and (c) fragmentation of $\left[\mathrm{UO}_{2}(\mathrm{aco})_{3}\right]^{2+}$. Photodissociation spectra were collected using the FT-ICR mass spectrometer.

Figure 7. IR photodissociation spectra generated from uranyl-aco complex ions: (a) fragmentation of $\left[\mathrm{UO}_{2}(\mathrm{aco})_{5}\right]^{2+}$, (b) fragmentation of $\left[\mathrm{UO}_{2}(\mathrm{aco})_{4}\right]^{2+}$ and (c) fragmentation of $\left[\mathrm{UO}_{2}(\mathrm{aco})_{3}\right]^{2+}$. Photodissociation spectra were collected using the linear ion trap mass spectrometer.

Table 1. Measured and calculated exact masses for the uranyl-acetone precursor and product ions. 


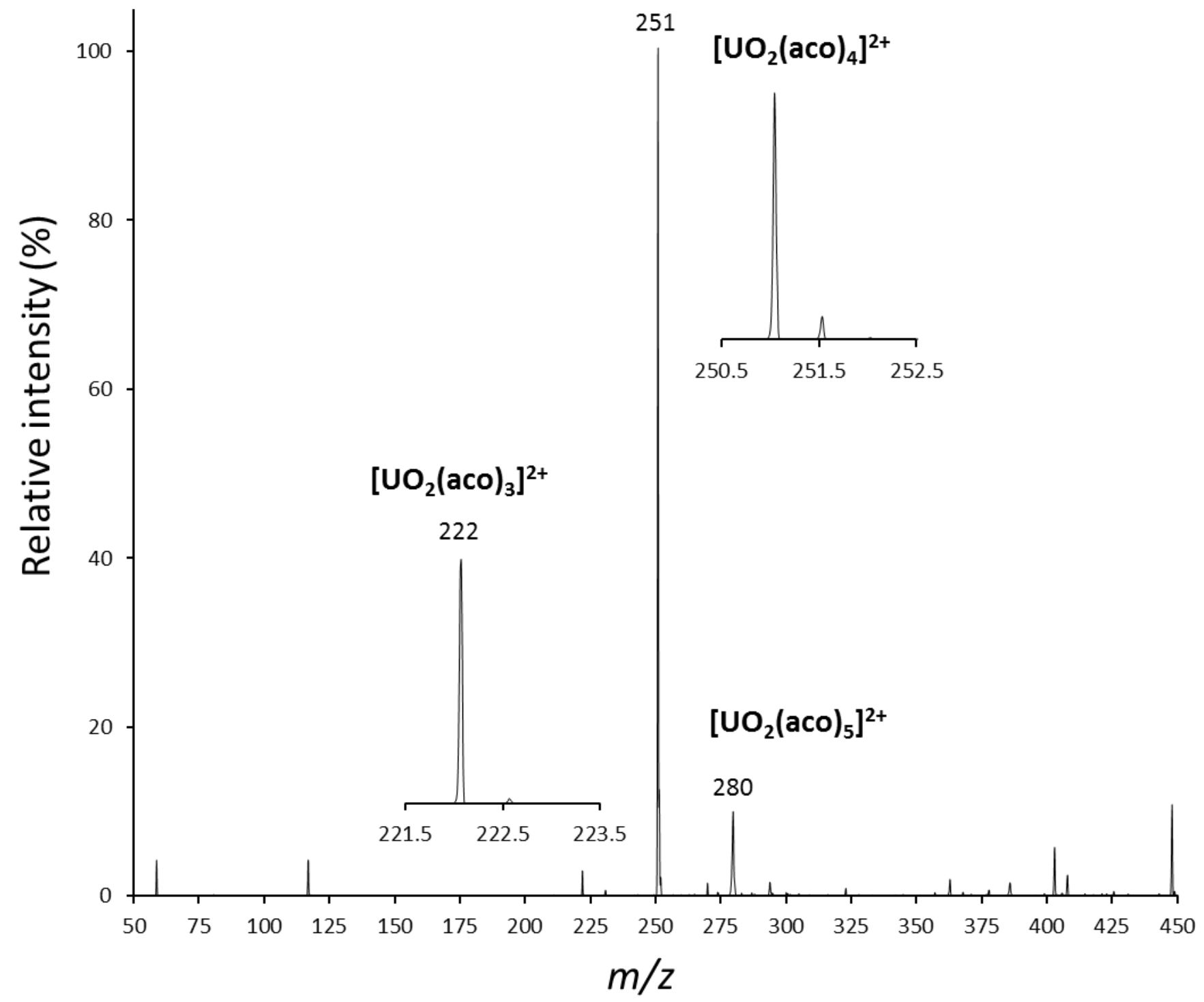

Figure 1. 


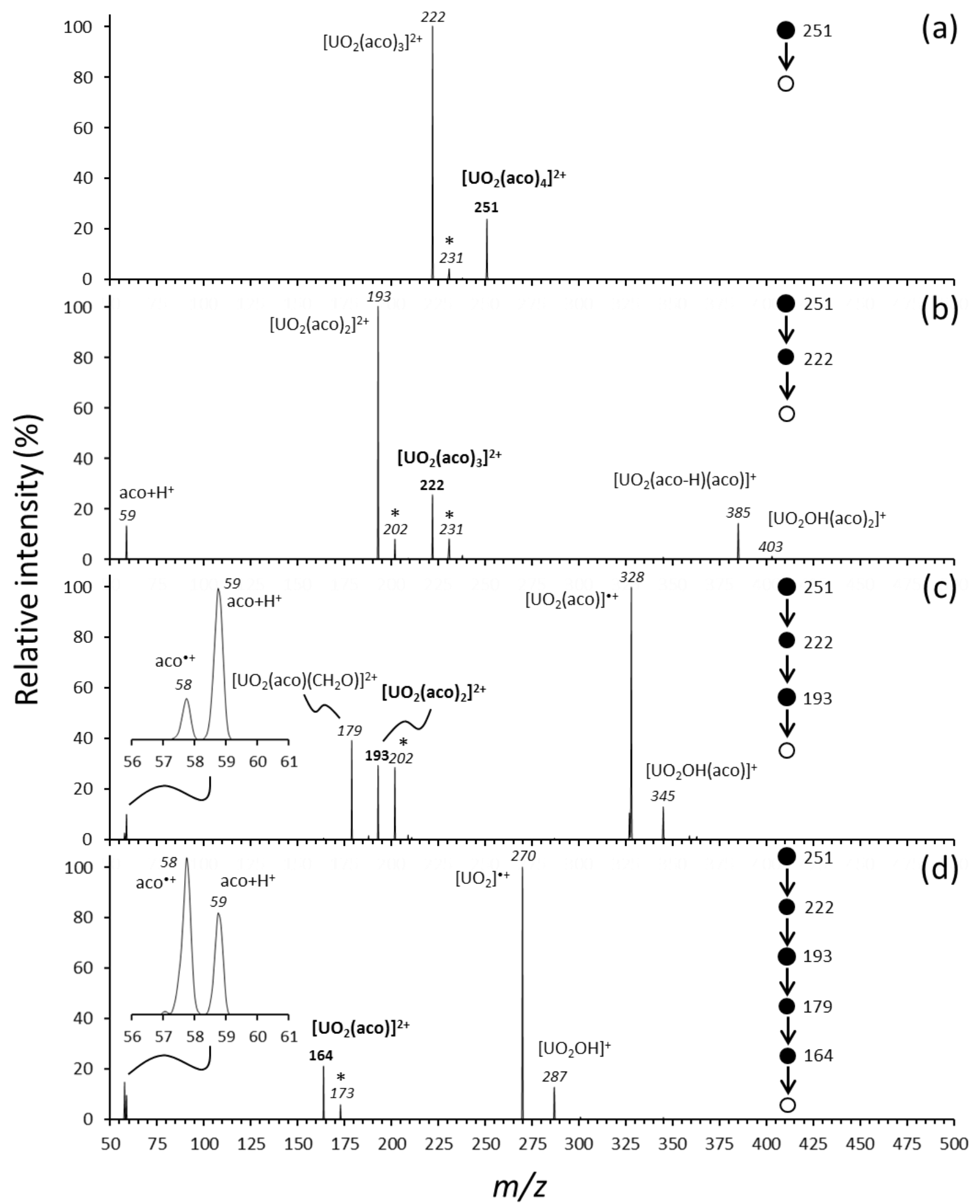

Figure 2. 


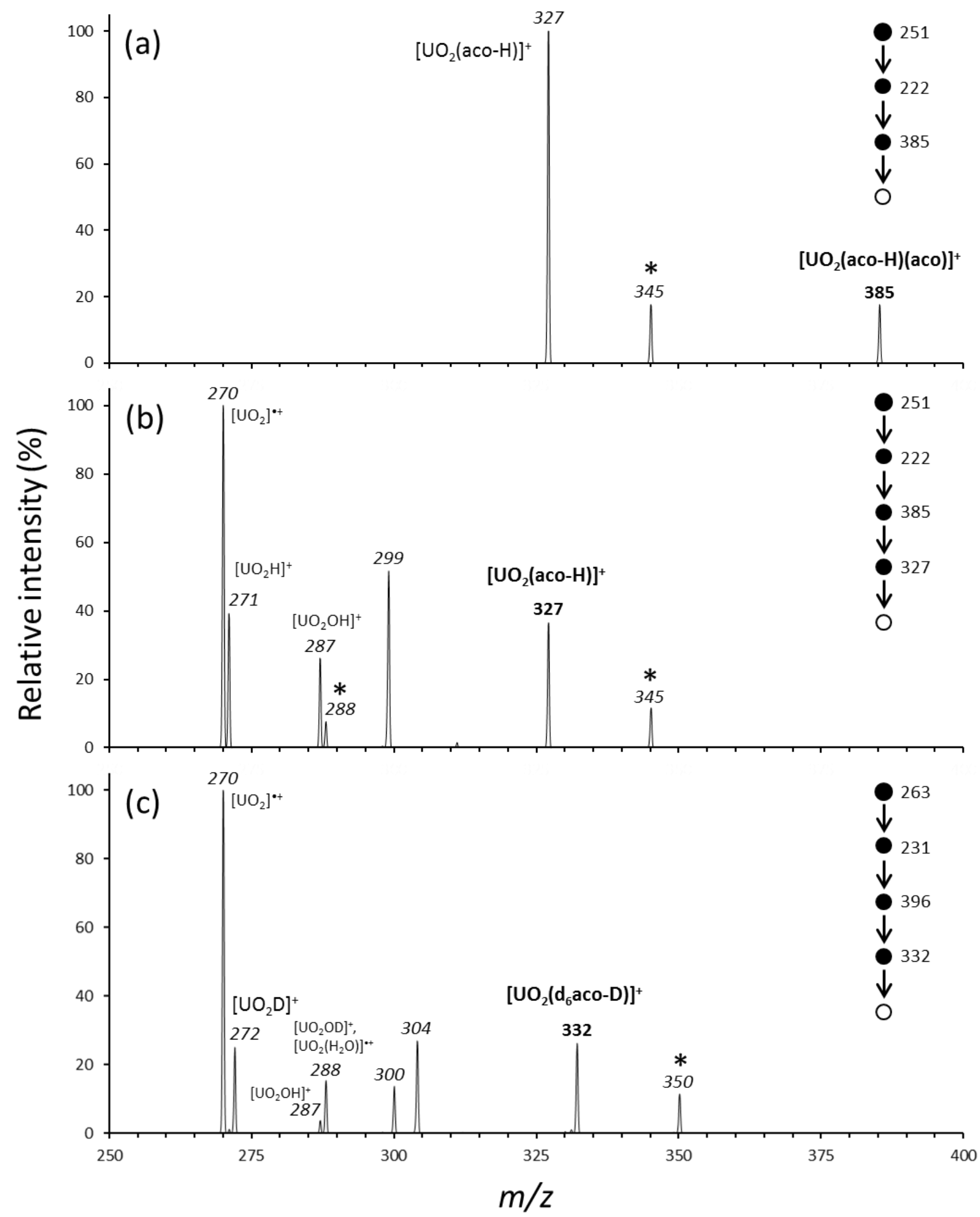

Figure 3. 


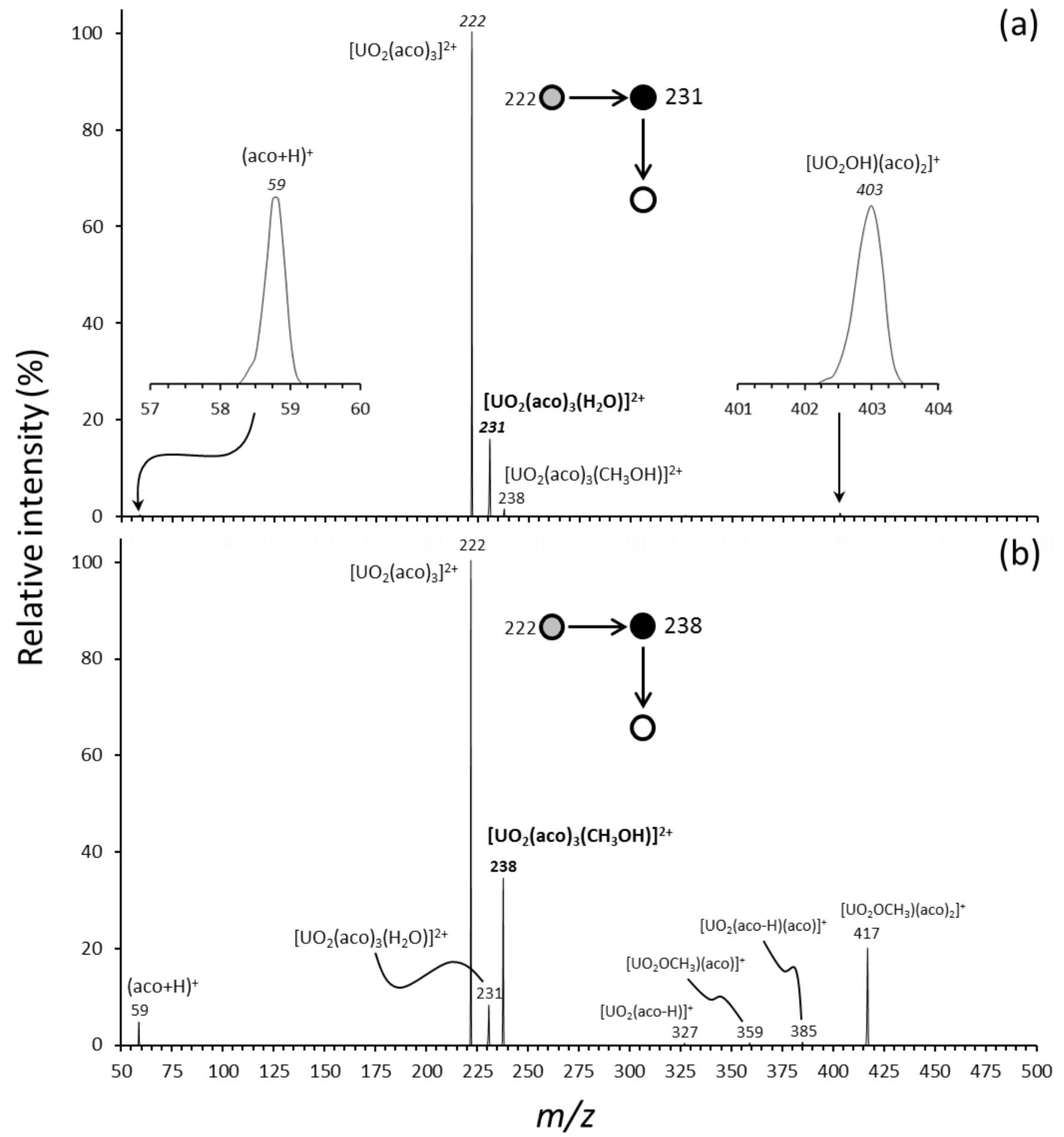

Figure 4 . 


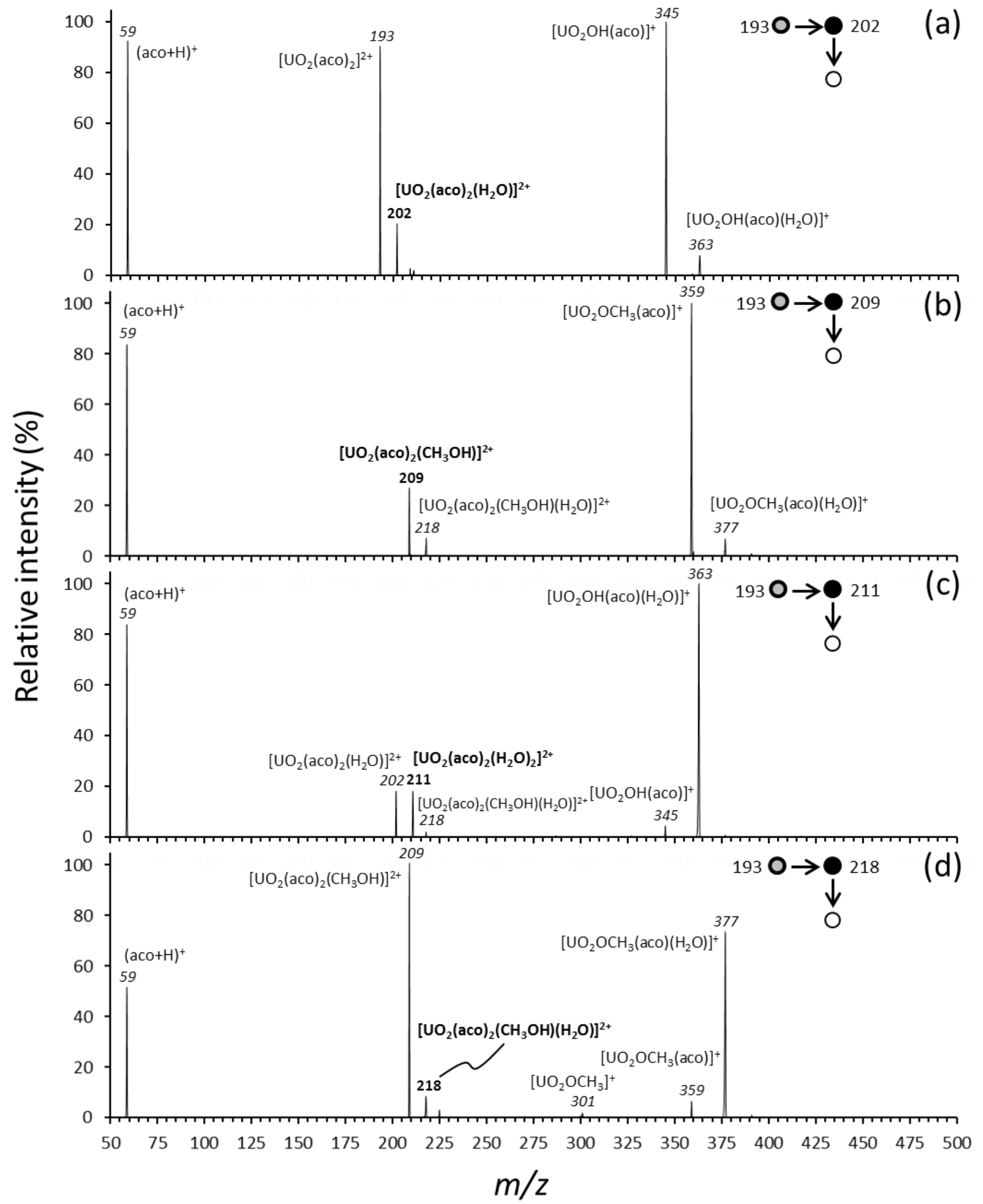

Figure 5. 


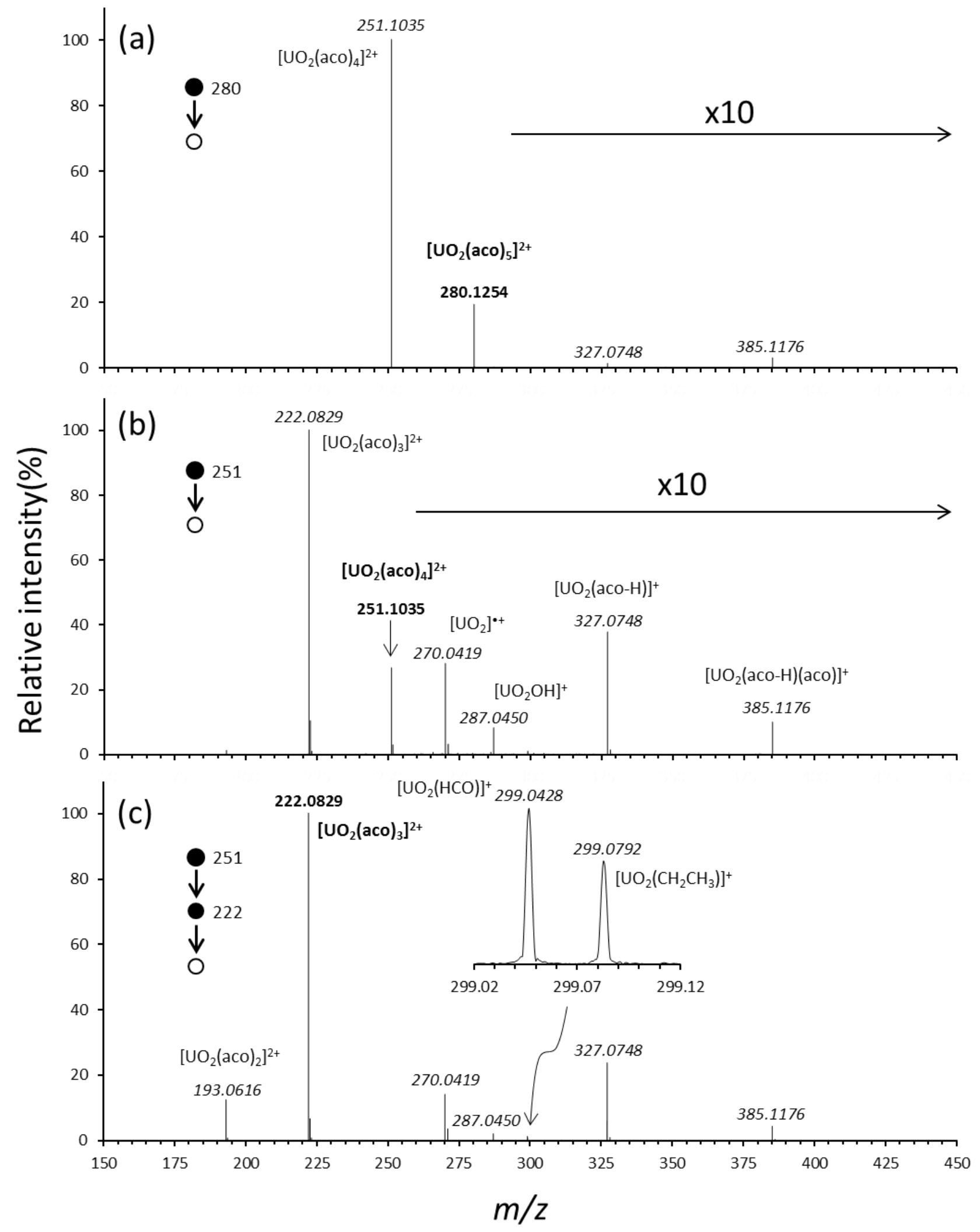

Figure 6. 


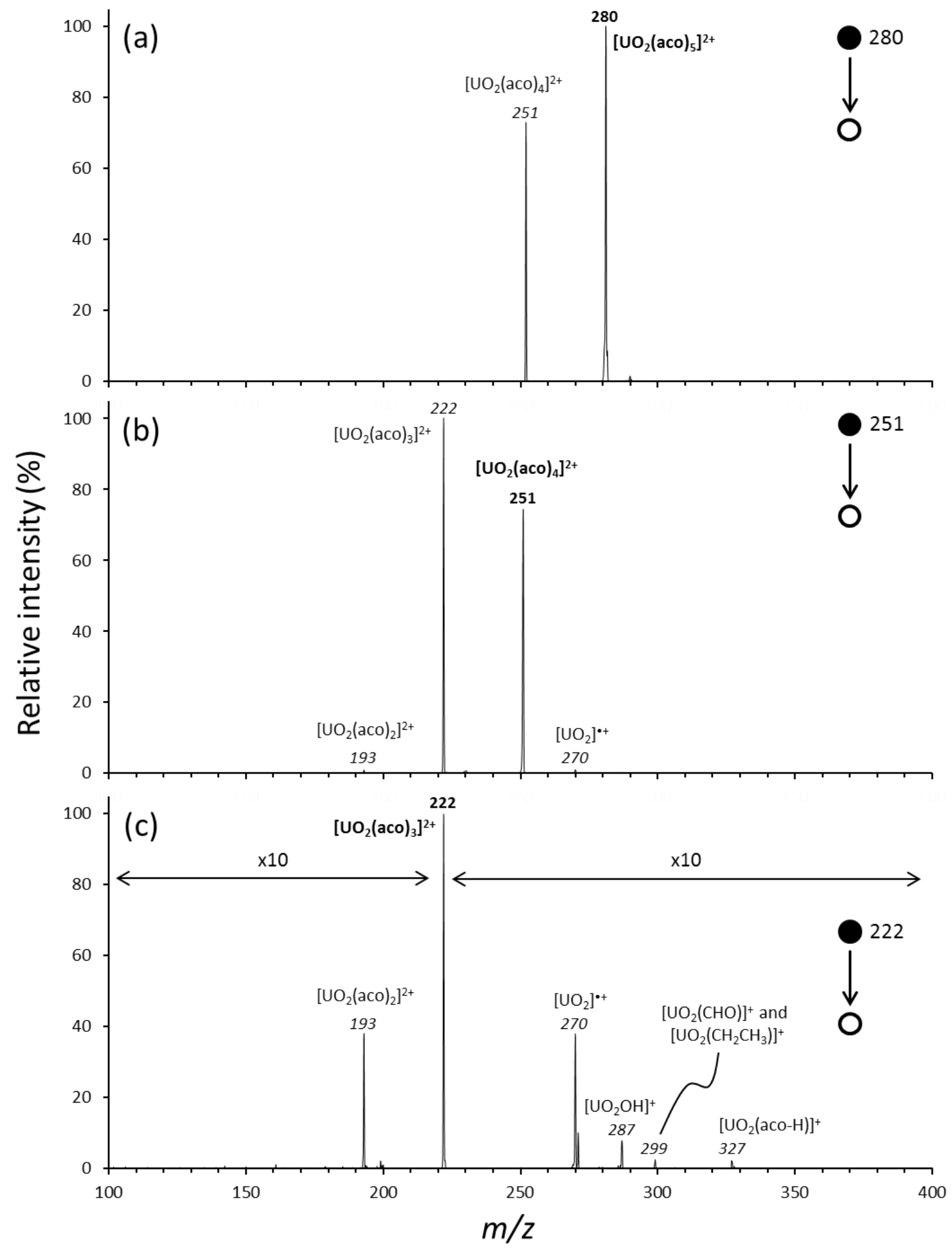

Figure 7. 
Table 1.

\begin{tabular}{|c|c|c|c|c|}
\hline Measured $m / z$ & Calculated $m / z$ & Error (ppm) & $\begin{array}{l}\text { Molecular } \\
\text { formula }\end{array}$ & $\begin{array}{l}\text { Composition } \\
\text { assignment }\end{array}$ \\
\hline 280.1254 & 280.1244 & 3.6 & $\mathrm{UO}_{7} \mathrm{C}_{15} \mathrm{H}_{30}$ & {$\left[\mathrm{UO}_{2}(\mathrm{aco})_{5}\right]^{2+}$} \\
\hline 251.1037 & 251.1035 & 0.8 & $\mathrm{UO}_{6} \mathrm{C}_{12} \mathrm{H}_{24}$ & {$\left[\mathrm{UO}_{2}(\mathrm{aco})_{4}\right]^{2+}$} \\
\hline 222.0829 & 222.0825 & 1.8 & $\mathrm{UO}_{5} \mathrm{C}_{9} \mathrm{H}_{18}$ & {$\left[\mathrm{UO}_{2}(\mathrm{aco})_{3}\right]^{2+}$} \\
\hline 193.0619 & 193.0616 & 1.6 & $\mathrm{UO}_{4} \mathrm{C}_{6} \mathrm{H}_{12}$ & {$\left[\mathrm{UO}_{2}(\mathrm{aco})_{2}\right]^{2+}$} \\
\hline 385.1176 & 385.1159 & 4.4 & $\mathrm{UO}_{4} \mathrm{C}_{6} \mathrm{H}_{11}$ & {$\left[\mathrm{UO}_{2}(\mathrm{aco}-\mathrm{H})(\mathrm{aco})\right]^{]}$} \\
\hline 327.1748 & 327.0741 & 2.1 & $\mathrm{UO}_{3} \mathrm{C}_{3} \mathrm{H}_{5}$ & {$\left[\mathrm{UO}_{2}(\mathrm{aco}-\mathrm{H})\right]^{+}$} \\
\hline 299.0452 & 299.0428 & 8.0 & $\mathrm{UO}_{3} \mathrm{CH}$ & {$\left[\mathrm{UO}_{2}(\mathrm{HCO})\right]^{+}$} \\
\hline 299.0812 & 299.0792 & 6.7 & $\mathrm{UO}_{2} \mathrm{C}_{2} \mathrm{H}_{5}$ & {$\left[\mathrm{UO}_{2}\left(\mathrm{CH}_{2} \mathrm{CH}_{3}\right)\right]^{+}$} \\
\hline 287.0450 & 287.0428 & 7.7 & $\mathrm{UO}_{3} \mathrm{H}$ & {$\left[\mathrm{UO}_{2} \mathrm{OH}\right]^{+}$} \\
\hline 271.0497 & 271.0478 & 7.0 & $\mathrm{UO}_{2} \mathrm{H}$ & {$\left[\mathrm{UO}_{2} \mathrm{H}\right]^{+}$} \\
\hline 270.0419 & 270.04 & 7.0 & $\mathrm{UO}_{2}$ & {$\left[\mathrm{UO}_{2}\right]^{+}$} \\
\hline
\end{tabular}

